\title{
Active and passive biomonitoring suggest metabolic adaptation in blue mussels (Mytilus spp.) chronically exposed to a moderate contamination in Brest harbor (France)
}

\author{
Lacroix Camille ${ }^{1,{ }^{*}}$, Richard Gaelle ${ }^{1}$, Seguineau Catherine ${ }^{1,2}$, Guyomarch Julien ${ }^{3}$, Moraga Dario ${ }^{1}$, \\ Auffret Michel ${ }^{1}$
}

${ }^{1}$ LEMAR-UMR 6539 UBO/CNRS/IRD/Ifremer-Institut Universitaire Européen de la Mer, Université de Bretagne Occidentale, 29280 Plouzané, France

2 LPI-UMR 6539-IFREMER, 29280 Plouzané, France

${ }^{3}$ CEDRE-715, Rue Alain Colas/CS 41836-29218 Brest Cedex 2, France

* Corresponding author : Camille Lacroix, Tel.: +33 298498627 ; email address : camlacroix@hotmail.fr

\begin{abstract}
:
Brest harbor (Bay of Brest, Brittany, France) has a severe past of anthropogenic chemical contamination, but inputs tended to decrease, indicating a reassessment of its ecotoxicological status should be carried out. Here, native and caged mussels (Mytilus spp.) were used in combination to evaluate biological effects of chronic chemical contamination in Brest harbor. Polycyclic aromatic hydrocarbon (PAH) contamination was measured in mussel tissues as a proxy of harbor and urban pollution. Biochemical biomarkers of xenobiotic biotransformation, antioxidant defenses, generation of reducing equivalents, energy metabolism and oxidative damage were studied in both gills and digestive glands of native and caged mussels. In particular, activities of glutathione-S-transferase (GST), superoxide dismutase (SOD), catalase (CAT), glutathione peroxidase (GPx), glutathione reductase (GR), NADP-dependent isocitrate dehydrogenase (IDP), pyruvate kinase (PK) and phosphoenolpyruvate carboxykinase (PEPCK) were measured and lipid peroxidation was assessed by malondialdehyde (MDA) quantification. In addition, a condition index was calculated to assess the overall health of the mussels. Moderate PAH contamination was detected in digestive glands of both native and caged individuals from the exposed site. Modulations of biomarkers were detected in digestive glands of native harbor mussels indicating the presence of a chemical pressure. In particular, results suggested increased biotransformation (GST), antioxidant defenses (CAT), NADPH generation (IDP) and gluconeogenesis (PEPCK), which could represent a coordinated response against chemically-induced cellular stress. Lipid peroxidation assessment and condition index indicated an absence of acute stress in the same mussels suggesting metabolic changes could, at least partially, offset the negative effects of contamination. In caged mussels, only GR was found modulated compared to non-exposed mussels but significant differences in oxidative stress and energy-related biomarkers were observed compared to native harbor mussels. Overall, these results suggested mussels chronically exposed to contamination have set up metabolic adaptation, which may contribute to their survival in the moderately contaminated harbor of Brest. Whether these adaptive traits result from
\end{abstract}


phenotypic plasticity or genetic adaptation needs to be further investigated.

\section{Highlights}

- A biomonitoring study was carried out in Brest harbor using native and caged mussels. Moderate polycyclic aromatic hydrocarbon contamination was measured in Brest harbor. Chronic exposure induced biotransformation, antioxidants and gluconeogenesis in mussels. One month caging induced bioaccumulation but weak biomarker responses in mussels. Condition index indicated absence of acute physiological stress in exposed mussels.

Keywords: Marine biomonitoring, Chronic pollution, Blue mussel Mytilus spp., Caging, Oxidative stress, Energetic metabolism, Bay of Brest 


\section{Introduction}

Releases to the marine environment have decreased in Western Europe over the last 20 years for several groups of contaminants due to environmental regulation initiated by international authorities (e.g. the European or the OSPAR commission). However, in many coastal regions, chronic chemical contamination remains a problem (OSPAR Commission, 2009) and further actions are required to achieve or maintain good water quality in marine environments. Regarding chemical pollution, according to the European Marine Strategy Framework Directive (2008/56/EC), a good environmental status in marine environments signifies that "concentrations of contaminants are at levels not giving rise to pollution effects" (European Commission, 2008).

To assess pollution effects on aquatic ecosystems, biomonitoring, i.e. the study of biological responses of exposed organisms, appears to be an appropriate method. First, biological matrices offer a time-integrated and reliable way of quantifying pollution, whereas water measurements are highly subjected to environmental variability, providing only punctuated insights of contamination levels (Andral et al., 2004; Besse et al., 2012). Furthermore, the use of ecotoxicological biomarkers allows the assessment of the real effects of pollutants on organism health, providing an early warning signal of deleterious effects due to pollution before they reach higher levels of biological organization (e.g. populations and ecosystems) (Depledge and Fossi, 1994; Monserrat et al., 2007).

Blue mussels (Mytilus spp.) have been extensively used as bioindicator (tissue concentration measurements) and/or sentinel (biomarker measurements) species to assess coastal water quality in biomonitoring studies. These sedentary, filter-feeder organisms are able to bioaccumulate and tolerate high amounts of pollutant and their broad geographical distribution, abundance and accessibility make them species of choice in large-scale and longterm marine monitoring programs (Farrington et al., 1983; Andral et al., 2004; Regoli et al., 2014; Melwani et al., 2014).

Two different strategies can be used in biomonitoring: passive or active. Passive biomonitoring relies on native individuals whereas the active approach is based on caged 
organisms from a reference site. The passive approach has been used for several decades due to its simplicity and the possibility to set-up long-term measurements, while the active approach has been introduced more recently to compensate for the limits of the first approach (Sericano et al., 1995; Besse et al., 2012). Though the caging procedure may affect organisms (Pampanin et al., 2005), it allows i) a reduction of the genetic and physiological variability by using a single population, ii) a control of exposure time, iii) an inter-site comparison regardless of the physicochemical and trophic conditions and iv) a compensation for the absence of native organisms and has been successfully applied in multiple biomonitoring studies (Andral et al., 2004; Khan et al., 2011; Besse et al., 2012; Dabrowska et al., 2013; Turja et al., 2013 and 2014).

Among enzymatic biomarkers commonly used in biomonitoring, glutathione-Stransferases (GSTs) are multi-isoform enzymes involved in phase-II xenobiotic and toxin biotransformation. It catalyzes the conjugation of reduced glutathione (GSH) to xenobiotic compounds, increasing their water solubility and excretion rate (Lima et al., 2007; Doyen et al., 2008). GSTs are also known to play a role in the redox cycle, especially antioxidant defenses, via inactivation of reactive oxygen species (ROS) or peroxidation products (Doyen et al., 2008). Many stressors potentially disturb organisms' redox status and induce oxidative stress, including chemical contamination (Kültz, 2005; Regoli and Giuliani, 2014). Antioxidant enzymes have been extensively used as non-specific biomarkers in biomonitoring to measure exposure and biological effects of aquatic pollution (for a review see Valavanidis et al., 2006). Most toxicants are known to alter the cellular balance between prooxidant challenge and antioxidant defenses via antioxidant capacity depression and/or enhancement of ROS production, resulting in modulation of antioxidant defenses and potentially oxidative stress such as lipid peroxidation (Valavanidis et al., 2006; Regoli and Giuliani, 2014). Among effectors of antioxidant defenses, superoxide dismutase (SOD) isoforms catalyze the conversion of superoxide anion into hydrogen peroxide $\left(\mathrm{H}_{2} \mathrm{O}_{2}\right)$ that is subsequently converted into water thanks to catalase (CAT) and/or glutathione peroxidase (GPx) action (Regoli and Giuliani, 2014). Enzymes involved in reducing equivalents generation are also potential biomarkers. Glutathione reductase (GR) is involved in the reduction of oxidized glutathione (GSSG) to GSH, subsequently needed by antioxidant and biotransformation enzymes (e.g. GPx and GST) for ROS and xenobiotic detoxification (Regoli and Giuliani, 2014). NADP-dependent isocitrate dehydrogenases (IDP) participate in NADPH regeneration. NADPH is involved in lipid synthesis and could be implicated in antioxidant defenses and biotransformation since it is a cofactor of GR and is also needed by the mixed-function oxidase system involved in phase I of biotransformation (Moore et al., 1980; Gabbott and Head, 1980; Jo et al., 2001; Regoli and Giuliani, 2014). Though less explored, modulation of energetic metabolism is another key aspect of the chemical stress response, and energy related biomarkers can be useful tools to assess physiological stress 
(Kültz, 2005; Sokolova et al., 2012). Energetic metabolism can be affected directly and/or indirectly by pollution via disruption of ATP-producing pathways and increased metabolic costs (Sokolova et al., 2012). Pyruvate kinase (PK) is a key energy enzyme catalyzing the last stage of glycolysis: the irreversible conversion of phosphoenolpyruvate (PEP) into pyruvate (Cameselle et al., 1980). Phosphoenolpyruvate carboxykinase (PEPCK) is involved in both gluconeogenesis and anaerobic pathways of energy production by catalyzing the reversible decarboxylation of oxaloacetate to PEP. The decarboxylation reaction enables glucose and glycogen synthesis from non-hexose precursors (e.g. pyruvate) (De Zwaan et al., 1973) whereas the reverse reaction (from PEP to oxaloacetate) enables the derivation of glycolysis towards mitochondrial anaerobic pathways in hypoxic and anoxic conditions, competing with PK and forming the PEPbranchpoint (Greenway and Storey, 1999; Sussarellu et al., 2012).

Located in the semi-enclosed Bay of Brest (Brittany, France), Brest harbor has a severe past of chronic chemical contamination resulting from anthropogenic activities and several works previously reported clear signs of impaired marine organisms health in this area (Huet et al., 1996; Donval and Plana, 1997; Glémarec, 1997; Michel and Averty, 1997; Oubella, 1997; Quiniou et al., 1997). However, inputs tended to decrease during the last decade (Guermeur et al., 2005; Ifremer, 2006) and we could hypothesize an enhancement of Brest harbor ecotoxicological status. In this context, the objective of the present study was to study the effects of chronic chemical contamination using both an active and passive biomonitoring strategy with blue mussels (Mytilus spp.) as a sentinel/bioindicator species in order to assess the current ecotoxicological status of Brest harbor. To assess harbor and urban pollution, polycyclic aromatic hydrocarbon $(\mathrm{PAH})$ contamination was measured in digestive glands of both native and caged mussels. Regarding biological effects of contamination, several markers were used to assess the physiological status of native and caged mussels. At the biochemical level, biomarkers of xenobiotic biotransformation (GST), antioxidant defenses (SOD, CAT and GPx), reducing equivalents generation (GR and IDP), energetic metabolism (PK and PEPCK) and lipid peroxidation (malondialdehyde (MDA) quantification) were measured in gills and digestive glands of native and caged mussels. These organs were chosen since they are the first tissue barriers between the organism and its environment and are known to respond to chemical stress (Zhang et al., 2014). A condition index (CI), which provides an ecophysiological measure of mussels' overall health (Pampanin et al., 2005), was also calculated prior to and post caging.

\section{Materials and methods}

\subsection{Sampling sites and caging procedure}


Two sampling sites differentially exposed to chronic chemical contamination were chosen in the Bay of Brest (Brittany, France). Sampling sites were designated as follows: "Commercial Port" (Cp, 48 22' 51.59"N, 4 28' 59.50"W), an exposed site located in Brest harbor area and "Armorique" (Ar, 48 19' 20.29"N, 4 27' 13.51"W) located in the central part of the Bay and selected as a non-harbor reference site (Fig 1). The Commercial Port ( $\mathrm{Cp}$ ) has a severe record of chemical contamination and high concentrations of PAHs, polychlorinated biphenyls (PCBs), copper and tributyltin (TBT) were reported by previous studies, in sediments of this site (Michel and Averty, 1997; Quiniou et al., 1997). In August 2012, a batch of intertidal mussels (Mytilus spp.) native to the Armorique site (Ar), referred to as "Transplant" (Tr) were caged for one month at the Commercial Port ( $\mathrm{Cp}$ ) (near intertidal native mussels). After one month, native and caged intertidal mussels were sampled at low tide. Surface water quality measurements (Temperature, dissolved oxygen, salinity, $\mathrm{pH}$ and total dissolved solids) were performed in each site prior to and post caging, and are reported in Lacroix et al. (2014a). Surviving caged mussels were counted and compared to the initial number. A low mortality (less than 5\%) was observed in caged mussels, probably due to handling stress during caging procedure. Mussels were transported in cold containers from sampling sites to the laboratory where they were prepared for PAHs quantification, biochemistry analyses and CI calculation as described below. As sampling sites are located within a hybrid zone between M. edulis and M. galloprovincialis (Bierne et al., 2003), mussels used for biochemistry analyses were genotyped as either M. edulis, M. galloprovincialis or hybrid using the Me15/16 marker as described by Inoue et al. (1995). Genotyping results indicated that, regardless of the mussel group ( $\mathrm{Ar}, \mathrm{Cp}$ or $\mathrm{Tr}$ ), $M$. galloprovincialis and hybrid genotypes accounted for around 70 and $20 \%$ of mussels, respectively, and only one M. edulis genotype was identified (data not shown). To reduce the possible influence of the species factor on results and due to their low number, $M$ edulis genotypes were removed and only M. galloprovincialis and hybrid genotypes were kept for biochemical marker analyses. Since existence of introgressions between Mytilus species prevents a reliable identification using a single marker (Bierne et al., 2003; Kijewski et al., 2011), M. galloprovincialis and hybrid genotypes were considered as a homogenous group (Mytilus spp.).

\subsection{PAHs bioaccumulation in mussel digestive glands}

Minimum of 12 mussels (mean length \pm standard deviation (S.D.): $52.2 \pm 3.5,84.8 \pm 4.0$ and $51.9 \pm 4.7 \mathrm{~mm}$ for $\mathrm{Ar}, \mathrm{Cp}$ and $\mathrm{Tr}$, respectively) per group were used to assess PAH contamination. Digestive glands were dissected, pooled ( 3 pools per mussel group) and kept at $-20^{\circ} \mathrm{C}$ before being freeze-dried with an Alpha 1-2LDplus freeze-dryer (Christ). Dried pools were then reduced into powder with mortar and pestle and $200 \mathrm{mg}$ were analyzed for individual PAH 
contamination by stir bar sorptive extraction-thermal desorption-gas chromatography-tandem mass spectrometry (SBSE-GC-MS/MS) as described and validated in Lacroix et al. (2014b). Results are expressed as individual PAH concentration ( $\mu \mathrm{g} / \mathrm{kg}$ dry weight (DW)). The abbreviations used for the 20 PAHs analyzed are: N (Naphthalene), BT (Benzothiophene), ANY (Acenaphthylene), ANA (Acenaphthene), F (Fluorene), DBT (Dibenzothiophene), P (Phenanthrene), A (Anthracene), FL (Fluoranthene), PY (Pyrene), BaA (Benzo(a)anthracene), C (Chrysene), BbF (Benzo(b)fluoranthene), BkF (Benzo(k)fluoranthene), BeP (Benzo(e)pyrene), BaP (Benzo(a)pyrene), PE (Perylene), IN (Indeno(1,2,3-cd)pyrene), DBA (Dibenzo(a,h)anthracene) and BPE (Benzo(g,h,i)perylene). Benzo(b+k)fluoranthene (B(b+k)F) is the sum of benzo(b)fluoranthene and benzo(k)fluoranthene. $\mathrm{T}$ (Triphenylene) and $\mathrm{BjF}$ (Benzo(j)fluoranthene) were also quantified as they co-eluted with Chrysene and Benzo(k)fluoranthene respectively. Consequently, co-eluting analytes were measured as a sum total.

\subsection{Biochemical markers}

\subsubsection{Samples preparation and total protein extraction}

The digestive glands and gills of 15 mussels per group (mean length \pm S.D.: $57.3 \pm 3.8$, 64.8 \pm 4.4 and $55.0 \pm 3.9 \mathrm{~mm}$ for $\mathrm{Ar}, \mathrm{Cp}$ and $\mathrm{Tr}$ respectively) were dissected, snap-frozen in liquid nitrogen and stored individually at $-80^{\circ} \mathrm{C}$. Digestive glands and gills were then pooled separately (total of 5 pools per organ per mussel group) and ground into powder under liquid nitrogen using a mixer mill MM400 (Retsch) to get homogenized pools. Then, total protein extractions were performed on $200 \mathrm{mg}$ of pool powder mixed in $1 \mathrm{ml}$ of lysis buffer [pH 7.4; $\mathrm{NaCl} 150 \mathrm{mM}$, Tris HCl 10 mM, EDTA 1 mM, EGTA 1 mM, phosphatase inhibitor cocktail II (Sigma-Aldrich) 1\%, Triton X-100 1\%, CA-Igepal ${ }^{\circledR}$ (Sigma-Aldrich) 0.5\%, sodium pyrophosphatase decahydrate $5 \mathrm{mM}$ and 1 tablets $/ 25 \mathrm{ml}$ of complete EDTA free protease inhibitor cocktail (Roche)] (Guévélou et al., 2013) using a Precellys ${ }^{\circledR} 24$ grinder coupled to a Cryolys ${ }^{\circledR}$ cooling system (Bertin technologies). Samples were subsequently centrifuged at $10000 \mathrm{~g}$ for $45 \mathrm{~min}$ at $4^{\circ} \mathrm{C}$ prior to supernatant collection, aliquoting and storage at $-80^{\circ} \mathrm{C}$.

\subsubsection{Enzymatic activities}

Glutathione-S-Transferase (GST, EC 2.5.1.18) enzymatic assays were performed in triplicate in microplates, as described in McFarland et al. (1999). Briefly, $200 \mu \mathrm{l}$ of reaction buffer (PBS 200 mM pH 6.5, L-glutathione reduced 1 mM, 1-chloro-2,4-dinitrobenzene (CDNB) 1 $\mathrm{mM}$ ) were added to $15 \mu \mathrm{l}$ of protein extracts and delta absorbance was recorded at $340 \mathrm{~nm}$ for 7 min. GST activities were expressed in $\mathrm{U} \mathrm{ml}^{-1}$ using the delta absorbance per minute and the 
CDNB molar extinction coefficient $\left(9.6 \mathrm{mM}^{-1} \mathrm{~cm}^{-1}\right)$. One unit of GST is defined as the amount of enzyme catalyzing $1 \mu \mathrm{mol}$ of CDNB per minute.

Total Superoxide Dismutase (Tot-SOD, EC 1.15.1.1) activity was measured using the Sigma-Aldrich SOD determination kit, according to manufacturer instructions for microplates. Prior to the assay, protein extracts were diluted 5 and 10 times for gill and digestive gland pools, respectively. Inhibition of xanthine oxidase was recorded at $450 \mathrm{~nm}$ and results were expressed in $\mathrm{U} \mathrm{mg}^{-1}$ proteins, one unit being defined as the amount of enzyme inhibiting by $50 \%$ the xanthine/xanthine oxidase complex. Mn-SOD activity was measured similarly except that KCN 5 $\mathrm{mM}$ was added to working solution to inhibit specifically $\mathrm{Cu} / \mathrm{Zn}$-SOD isoforms (Manduzio et al., 2003). Cu/Zn-SOD isoforms activity was obtained by subtracting Mn-SOD activity from total SOD activity.

Catalase (CAT, EC 1.11.1.6) enzymatic assays were performed in triplicate using cuvette and following the method of Aebi (1984). Briefly, $8 \mu \mathrm{l}$ of protein extracts were added to $792 \mu \mathrm{l}$ of reaction buffer (PBS $10 \mathrm{mM}, \mathrm{H}_{2} \mathrm{O}_{2} 10 \mathrm{mM}$ ) and delta absorbance was recorded at $240 \mathrm{~nm}$ for $90 \mathrm{~s}$. CAT activities were expressed in $\mathrm{U} \mathrm{ml}^{-1}$ using the delta absorbance per minute and the $\mathrm{H}_{2} \mathrm{O}_{2}$ molar extinction coefficient $\left(0.04 \mathrm{mM}^{-1} \mathrm{~cm}^{-1}\right)$. One unit of CAT is defined as the amount of enzyme catalyzing $1 \mu \mathrm{mol}$ of $\mathrm{H}_{2} \mathrm{O}_{2}$ per minute.

Total Glutathione Peroxidase (GPx, EC 1.11.1.9 (selenium-dependent) and EC 2.5.1.18 (non selenium-dependent)) enzymatic assays were performed in duplicate in microplate following a method adapted from Lawrence and Burk (1976). Briefly, $200 \mu \mathrm{l}$ of reaction buffer (PBS $50 \mathrm{mM} \mathrm{pH} \mathrm{7.4,} \mathrm{EDTA} 5 \mathrm{mM}$, L-glutathione reduced $2 \mathrm{mM}$, GR $2 \mathrm{U} \mathrm{ml}^{-1}$, NADPH $0.4 \mathrm{mM}$, Cumene hydroperoxide $1.5 \mathrm{mM}$ ) were added to $50 \mu$ l protein extracts (1:2) and delta absorbance was recorded at $340 \mathrm{~nm}$ for $7 \mathrm{~min}$. GPx activities were expressed in $\mathrm{U} \mathrm{ml}^{-1}$ using the delta absorbance per minute and the NADPH molar extinction coefficient $\left(6.22 \mathrm{mM}^{-1} \mathrm{~cm}^{-1}\right)$. One unit of GPx is defined as the amount of enzyme catalyzing the conversion of $1 \mu \mathrm{mol}$ of NADPH per minute.

Glutathione reductase (GR, EC 1.6.4.2) enzymatic assays were performed in triplicate, in microplate as described in Cribb et al. (1989). Briefly, $170 \mu \mathrm{l}$ of reaction buffer (PBS $100 \mathrm{mM} \mathrm{pH}$ 7.5, EDTA $0.9 \mathrm{mM}$, NADPH $0.63 \mathrm{mM}$, L-glutathione oxidized $0.17 \mathrm{mM}, 5,5^{\prime}$-dithiobis(2nitrobenzoic acid) (DTNB) $0.08 \mathrm{mM}$ ) were added to $20 \mu \mathrm{l}$ of protein extracts and delta absorbance was recorded at $412 \mathrm{~nm}$ for $3 \mathrm{~min}$. GR activities were expressed in $\mathrm{U} \mathrm{ml}^{-1}$ using the delta absorbance per minute and the DTNB molar extinction coefficient $\left(14.15 \mathrm{mM}^{-1} \mathrm{~cm}^{-1}\right)$. One unit of GR is defined as the amount of enzyme catalyzing $1 \mu \mathrm{mol}$ of DTNB per minute.

NADP-dependent Isocitrate Dehydrogenase (IDP, EC 1.1.1.42) assays was performed in duplicate in microplates following the method of Lockwood and Somero (2012). $180 \mu \mathrm{l}$ of reaction buffer (imidazole- $\mathrm{HCl} 100 \mathrm{mM}$ pH 7.2, NADP $0.15 \mathrm{mM}, \mathrm{MgCl}_{2} 4 \mathrm{mM}$, DL-isocitric acid 10 
$\mathrm{mM}$ ) were added to $20 \mu \mathrm{l}$ of protein extracts (1:1 and 1:10, respectively, for gills and digestive gland) and delta absorbance was recorded at $340 \mathrm{~nm}$ for $15 \mathrm{~min}$. Results were expressed as U $\mathrm{ml}^{-1}$ using the delta absorbance per minute and the NADPH molar extinction coefficient $(6.22$ $\mathrm{mM}^{-1} \mathrm{~cm}^{-1}$ ). One unit of IDP is defined as the amount of enzyme catalyzing the reduction of 1 $\mu$ mol of NADP per minute.

Pyruvate kinase (PK, EC 2.7.1.40) and phosphoenolpyruvate carboxykinase (PEPCK, EC 4.1.1.32) assays were performed in duplicate in microplates following the method of Greenway and Storey (1999). For PK assay, $180 \mu \mathrm{l}$ of reaction buffer (imidazole-HCl $100 \mathrm{mM} \mathrm{pH} \mathrm{7.2,} \mathrm{KCl} 50$ $\mathrm{mM}, \mathrm{MgCl}_{2} 5 \mathrm{mM}$, adenosine diphosphate $2 \mathrm{mM}$, NADH $0.15 \mathrm{mM}$, rotenone-saturated ethanol $0.2 \%(\mathrm{v} / \mathrm{v}$ ) and Lactate Dehydrogenase $1 \mathrm{U} / \mathrm{ml}$, phosphoenolpyruvate $10 \mathrm{mM}$ ) were added to 20 $\mu \mathrm{l}$ of protein extracts. For PEPCK, $180 \mu \mathrm{l}$ of reaction buffer (imidazole-HCl $100 \mathrm{mM} \mathrm{pH} \mathrm{6.6,} \mathrm{2-}$ mercaptoethanol $30 \mathrm{mM}, \mathrm{NaHCO}_{3} 50 \mathrm{mM}$, inosine diphosphate $1.25 \mathrm{mM}, \mathrm{MnCl}_{2} 1 \mathrm{mM}, \mathrm{NADH}$ $0.15 \mathrm{mM}$ and Malate Dehydrogenase $2.5 \mathrm{U} \mathrm{ml}^{-1}$, phosphoenolpyruvate $5 \mathrm{mM}$ ) were added to 20 $\mu \mathrm{l}$ of protein extracts (1:5). Delta absorbance was recorded at $340 \mathrm{~nm}$ for $15 \mathrm{~min}$. Results were expressed as $\mathrm{U} \mathrm{ml}^{-1}$ using the delta absorbance per minute and the NADH molar extinction coefficient $\left(6.22 \mathrm{mM}^{-1} \mathrm{~cm}^{-1}\right)$. One unit of PK or PEPCK is defined as the amount of enzyme catalyzing the oxidation of $1 \mu \mathrm{mol}$ of NADH per minute. A PK/PEPCK ratio was calculated for each mussel group for both organs by dividing mean PK by PEPCK activities for each sample.

Total protein concentration was measured in triplicate using the Quick Start ${ }^{\mathrm{TM}}$ Bradford Protein assay (Bio-rad), according to manufacturer instructions. Gills and digestive gland extracts were diluted 10 and 20 times respectively. Results were expressed in mg protein ml-1. Whole absorbances were read using a POLARstar Omega microplate reader (BMG Labtech) at $25^{\circ} \mathrm{C}$. All enzyme activities were normalized by protein concentration and finally expressed in $\mathrm{U} / \mathrm{mg}$ proteins.

\subsubsection{Lipid peroxidation assessment}

As polyunsaturated fatty acids-derived lipid peroxides are unstable and decompose to other complex compounds of which malondialdehyde (MDA) is the most abundant, lipid peroxidation was assessed using the MDA assay method, based on the formation of a MDA/TBA (thiobarbituric acid) complex as described in Béguel et al. (2013). 50mg of tissue powder were homogenized in $1 \mathrm{~mL}$ Milli-Q water containing $2 \%$ of a $1 \%$ butylhydroxytoluene methanol solution, using an Ultra-Turrax ${ }^{\circledR}(\mathrm{IKA}) .3 \mathrm{~mL}$ of a $1 \%$ phosphoric acid solution followed by $1 \mathrm{~mL}$ of a $1 \%$ TBA solution were then added. Solutions were incubated $30 \mathrm{~min}$ at $100^{\circ} \mathrm{C}$ and subsequently cooled on ice prior addition of $5 \mathrm{ml}$ of butanol. Phases were separated by centrifugation at $6000 \mathrm{~g}$ for $10 \mathrm{~min}$ at $4^{\circ} \mathrm{C}$ and the organic upper phase was then used to measure the absorbance of the MDA/TBA complex at $532 \mathrm{~nm}$. MDA concentrations were determined 
using a calibration curve using standards from 0 to $10 \mu \mathrm{mol} \mathrm{L}^{-1}$. Results were expressed as nmol MDA/g wet weight (WW) of tissue.

\subsection{Condition index}

Mussel overall condition was assessed in native and caged mussels by calculating a condition index (CI) relating shells and dry soft body mass. For each site, minimum of 12 mussels (mean length \pm S.D.: 53.8 $\pm 4.1,61.6 \pm 8.2$ and $56.2 \pm 3.4 \mathrm{~mm}$ for $\mathrm{Ar}, \mathrm{Cp}$ and $\mathrm{Tr}$, respectively) were cleaned from fouling and opened for dissection. Soft bodies were removed and then shells and soft parts were separately dried at $60^{\circ} \mathrm{C}$ for 7 days. Walne and Mann CI (\%o) was calculated according to the following formula:

$$
C I=1000 \times \frac{d r y \text { weight of meat }}{\text { dryweight of shell }}
$$

\subsection{Statistical analyses}

Statistics were performed using R software (R Core Team, 2013). Normality and homoscedasticity of variance were tested using Shapiro-Wilk and Bartlett tests, respectively ( $p>0.05)$. Condition index data were compared using one-way ANOVA followed by post hoc Tukey's HSD test when significant differences were observed. To assess differences in biochemical responses between sites, non-parametric Kruskal Wallis one-way analyses of variance followed by a post hoc Nemenyi-Damico-Wolfe-Dunn test and Principal Component Analysis (PCA) were performed. Levels of statistical significance were set at $p<0.05$.

\section{Results}

\subsection{PAH bioaccumulation in digestive glands of native and caged mussels}

Concentrations obtained for individual PAHs in digestive glands of native and caged mussels are shown in Table 1. In native mussels from the reference site (Ar), only one compound was quantified $(\mathrm{N})$ whereas the concentrations of 16 and 18 PAHs were above the limits of quantification (LOQs) in Cp and Tr mussels, respectively. Regarding individual PAHs, higher concentrations were recorded in caged mussels ( $\mathrm{Tr}$ ) as compared to native harbor mussels ( $\mathrm{Cp}$ ), regardless of the compound. In particular, more than a 2-fold mean difference was observed between native $(\mathrm{Cp})$ and caged (Tr) harbor mussels for P, A, FL, PY and $\mathrm{C}+\mathrm{T}$ concentrations, differences being maximum for FL and PY that exhibited a 4.3- and 3.2-fold difference, respectively. Among the PAHs analyzed, 16 are listed as priority pollutants by the United States Environmental Protection Agency (US EPA) (Yan et al., 2004). The sum ( \pm S.D.) of the 16 US EPA PAHs was the highest in caged mussels (Tr: $507 \pm 32 \mu \mathrm{g} / \mathrm{kg} \mathrm{DW}$ ), being 2.0 -fold higher than in native harbor mussels (Cp: $256 \pm 36 \mu \mathrm{g} / \mathrm{kg} \mathrm{DW}$ ). 
FL and PY ratios are indicative of PAH origins (pyrolytic or petrogenic). FL and PY ratios obtained for native and caged mussels sampled in the harbor site are shown in Table 2. For both groups, FL/PY ratios were below 1 indicating a petrogenic origin of PAH contamination. Results were less clear with $\mathrm{FL} /(\mathrm{FL}+\mathrm{PY})$ ratios, as the ratio was below 0.4 in $\mathrm{Cp}$ mussels $(0.37 \pm 0.01)$ but above 0.4 in $\operatorname{Tr}$ mussels $(0.45 \pm 0.00), 0.4$ being the threshold segregating petrogenic and pyrolytic origins for this ratio (Ruiz et al., 2011).

\subsection{Biochemical biomarkers}

GST activity levels in gills and digestive glands of mussels from the three groups are shown in Fig 2. Similar profiles were observed in both organs with the highest activities recorded in native harbor mussels (Cp). Higher GST activities were measured in $\mathrm{Cp}$ compared to reference mussels $(\mathrm{Ar})$, though they were only significant in the digestive gland $(p=0.004)$. Significantly higher GST activities were also observed in gills of native harbor mussels (Cp) compared to caged one $(\mathrm{Tr})(\mathrm{p}<0.001)$ and a similar though non-significant trend was observed in the digestive gland $(\mathrm{p}=0.089)$.

Antioxidant enzymes activities in gills and/or digestive gland of mussels from the three groups (Ar, Cp and Tr) are shown in Fig 3. Regarding Tot-SOD, higher activities were measured in native harbor mussels $(\mathrm{Cp})$ in both organs but only differences with caged mussels (Tr) were significant (in gills: p-values are 0.009 and 0.171 compared to $\mathrm{Tr}$ and Ar, respectively; in digestive glands: p-values are 0.0005 and 0.059 compared to $\mathrm{Tr}$ and $\mathrm{Ar}$, respectively). Similar results were observed for $\mathrm{Cu} / \mathrm{Zn}$-SOD activities, for which significantly higher activities were measured in Cp mussels compared to Tr mussels in both organs (p-values of 0.004 and 0.001 in gills and digestive gland, respectively). Concerning Mn-SOD activity, no significant intergroup differences were observed regardless of the organ ( $p>0.05$, data not shown). For CAT, higher activity levels were recorded in digestive glands of harbor mussels $(\mathrm{Cp})$ compared to nonexposed mussels (Ar) ( $\mathrm{p}=0.009)$, and a similar trend was observed compared to caged mussels $(\mathrm{Tr})(\mathrm{p}=0.06)$. In gills, a significantly lower CAT activity was measured in caged mussels (Tr) compared to native harbor mussels $(\mathrm{Cp})(\mathrm{p}=0.017)$ but no differences were observed compared to non-exposed mussels (Ar). GPx activities were only measured in digestive gland and no differences were observed between mussel groups.

Regarding enzymes involved in reducing equivalents generation, results are shown in Fig. 4. Significantly lower GR activities were measured in gills of caged harbor mussels compared to non-exposed one (Ar) ( $\mathrm{p}=0.011)$. In digestive glands, only trends were observed, as levels tend to be higher in native harbor mussels ( $\mathrm{Cp}$ ) compared to non-exposed mussels (Ar) $(p=0.061)$. Regarding IDP in the digestive gland, a significantly higher enzyme activity was 
measured for Cp mussels compared to Ar and Tr mussels (p-values of 0.013 and 0.048, respectively), whereas no significant differences were observed in gills.

For energetic enzymes, PK and PEPCK, results are shown in Fig. 5. No significant intergroup differences were observed in PK activities regardless of the organ (p-values of 0.677 and 0.134 for gills and digestive glands, respectively). For PEPCK, significant differences were observed between sites in digestive glands since Cp mussels exhibited higher PEPCK activities as compared to $\mathrm{Ar}$ and $\operatorname{Tr}$ mussels (p-values of 0.005 and 0.024 , respectively) whereas no differences were observed in gills ( $p=0.181$ ). Regarding PK/PEPCK ratios (Fig. 6), Cp mussels exhibited significantly lower ratios compared to caged mussels (Tr) in digestive glands $(\mathrm{p}=0.013)$. In gills, PK/PEPCK ratio exhibited important intra-site variability and no significant differences were observed ( $\mathrm{p}=0.141$; data not shown).

Regarding lipid peroxidation, digestive glands of native harbor mussels ( $\mathrm{Cp}$ ) exhibited higher MDA concentrations though the difference was only significant compared to caged mussels (Tr) ( $p=0.009$ ) (Fig. 7). No significant differences were observed in gills ( $p=0.141)$.

\subsection{Principal component analysis}

PCA were performed for both organs to further explore antioxidant-related responses, namely GST, TOTot-SOD, CAT, GPx, GR and IDP activities and MDA levels. As shown in Fig 8, axes clearly discriminated native harbor mussels ( $\mathrm{Cp}$ ) from the two other groups (Ar and $\mathrm{Tr}$ ) in both organs. For each PCA, the two axes accounted for $86 \%$ and $67 \%$ of the total variance in digestive gland and gills, respectively. In the digestive gland, IDP (20\%), GST (18\%), Tot-SOD (17\%) and GR $(16 \%)$ were the parameters that most contributed to the first axis whereas the major contributors for the second axis were MDA (36\%) and GPx (31\%). Regarding gills, the parameters that most contributed to the first axis were CAT (30\%), Tot-SOD (27\%) and GST (25\%), whereas MDA (48\%) and IDP (38\%) contributed most to the second.

\subsection{Condition index}

No significant differences were observed in CI between caged and native mussels ( $\mathrm{Tr}, \mathrm{Cp}$ and Ar; ANOVA, p>0.05) (Fig 9).

\section{Discussion}

A biomonitoring approach using Mytilus spp. as the bioindicator/sentinel species was applied in Brest harbor to assess the impacts of chemical pollution due to anthropogenic activities on biota. As recommended by previous research, a combination of native and caged 
mussels was used to measure concentrations as well as biological effects of contamination (Nigro et al., 2006; Marigómez et al., 2013).

\subsection{Chemical contamination in Brest harbor}

PAH contamination was used as a proxy of urban and harbor pollution, as these pollutants, produced by either petrogenic or pyrolytic sources, are characteristically released by anthropogenic activities in urban and industrial areas before ending up in coastal and inland waters (Manoli and Samara, 1999). PAHs are of great concern as they are highly toxic and readily accumulated by marine organisms like bivalve mollusks (Lima et al., 2007). Sixteen PAHs are listed as priority pollutants by the US Environmental Protection Agency (EPA) and 15 as potentially genotoxic and carcinogenic by the Scientific Committee on Food of the European Union (Wenzl et al., 2006). In the present study, 256 $\pm 36 \mu \mathrm{g} / \mathrm{kg}$ DW PAHs were detected in digestive glands of native harbor mussels ( $\mathrm{Cp}$ ). Additionally, results indicated that after one month of caging, transplanted mussels (Tr) had strongly accumulated PAHs in their digestive glands $(507 \pm 32 \mu \mathrm{g} / \mathrm{kg} \mathrm{DW})$ as compared to mussels in the reference site (Ar). The very low contamination detected here $(4.1 \pm 0.4 \mu \mathrm{g} / \mathrm{kg}$ DW for the 16 US EPA PAHs) confirmed Ar as an appropriate reference site for PAH contamination. These results indicated the existence of anthropogenic pollution in Brest harbor area. These PAH concentrations are similar to those measured in the urban and industrial area of Alboraya (Spain), where a concentration of 78 $\mu \mathrm{g} / \mathrm{kg} \mathrm{WW}$ ) (which is equivalent to $390 \mu \mathrm{g} / \mathrm{kg} \mathrm{DW}$, assuming mussels contain $80 \%$ water on average; Okumus and Stirling, 1998) for 14 US EPA PAHs were recorded in digestive glands of native mussels (Porte et al., 2001). However, the concentrations measured in Brest harbor remained low as compared to some other urban and industrial areas of Europe. In Denia and Barcelona, two urban and/or industrial areas with intense shipping activities on the eastern coast of Spain, Porte et al. (2001) measured PAHs concentrations 2.7- and 4-fold higher, respectively, in the digestive glands of native mussels as compared to mussels caged in Brest harbor (Tr) (concentrations of $273 \mu \mathrm{g} / \mathrm{kg} \mathrm{WW}$ equivalent to $1365 \mu \mathrm{g} / \mathrm{kg} \mathrm{DW}$ and $405 \mu \mathrm{g} / \mathrm{kg}$ WW equivalent to $2025 \mu \mathrm{g} / \mathrm{kg} \mathrm{DW}$, respectively, for 14 US EPA PAHs). Along the eastern coastline of Sicily (Italy), Cappello et al. (2013) measured a 21-fold higher contamination for the 16 US EPA PAHs $(2139 \mu \mathrm{g} / \mathrm{kg} \mathrm{WW}$ equivalent to $10695 \mu \mathrm{g} / \mathrm{kg} \mathrm{DW})$ in the digestive glands of caged mussels as compared to Tr mussels. Overall, our results indicate that Brest harbor experiences moderate PAH contamination, which probably mainly results from petrogenic origin (due to shipping activities) as suggested by the relationships between FL and PY.

\subsection{Effects of chemical contamination on biomarker responses in native mussels}


In digestive glands of native harbor mussels ( $\mathrm{Cp}$ ), significant changes were observed in activities of enzymes involved in xenobiotics, oxyradicals and energy metabolism as compared to non-exposed mussels (Ar). This is in agreement with the existence of some chemical pressure in Brest harbor and confirms results obtained at the transcriptional level in gills of the same mussels where higher expressions of genes involved in phase I and II biotransformation ( $\pi$-gst and cytochrome p450-3-like-2, respectively) and in antioxidant defenses (Cu/Zn-sod) were described (Lacroix et al., 2014a).

Here, higher GST activities suggested an enhancement of xenobiotic biotransformation processes and could also play a role in ROS scavenging in digestive glands of native harbor mussels (Cp). Induction of GST in native mussels inhabiting polluted areas has been reported in several field studies (Gowland et al., 2002; Rocher et al., 2006; Serafim et al., 2011) and it has been proposed as a useful biomarker for long-term monitoring in marine coastal areas (VidalLiñán et al., 2010).

Regarding antioxidant defenses, higher antioxidant enzyme activities were observed in native harbor mussel ( $\mathrm{Cp}$ ) digestive glands as compared to non-exposed ones (Ar). This suggested an increased ROS production and an activation of antioxidant defenses to maintain the redox balance and prevent oxidative stress. In particular, the trend of higher Tot-SOD activities (mainly mediated by $\mathrm{Cu} / \mathrm{Zn}$ isoforms) suggested increased dismutation rates of superoxide anions into $\mathrm{H}_{2} \mathrm{O}_{2}$ while induction of CAT could be a response to an increase in cellular $\mathrm{H}_{2} \mathrm{O}_{2}$ concentration. This may represent a coordinated action to remove the chemically-induced production of superoxide anions, which is supported by PCA as Tot-SOD and CAT positively covaried in native harbor mussel digestive glands. Induction of CAT and/or SOD activities in polluted areas has been reported in several field studies involving mussels (Lima et al., 2007; Vlahogianni et al., 2007). Regarding GPx, no changes were observed in digestive glands of native harbor mussels. This confirms that CAT, which has a high efficiency and a low affinity for $\mathrm{H}_{2} \mathrm{O}_{2}$, is preferred during peaks of $\mathrm{H}_{2} \mathrm{O}_{2}$ production or accumulation whereas GPx could be mainly involved in removing physiologically produced $\mathrm{H}_{2} \mathrm{O}_{2}$ (Pamplona and Costantini, 2011).

Changes were also observed for enzymes involved in reducing equivalents generation. For GR, activities tended to be higher in digestive glands of native harbor mussels suggesting a higher GSH production, which could subsequently be involved in ROS scavenging and phase-II biotransformation. Induction of GR activities has been previously reported in response to contamination in mussel digestive glands (Turja et al., 2013). Regarding IDP, higher activities were observed in digestive glands of native harbor mussels $(\mathrm{Cp})$ suggesting an increase NADPH generation in this organ since NADP-isocitrate dehydrogenases are among the important sources of NADPH with the pentose-phosphate pathway (Gabbott et Head, 1980). NADPH could be further involved in the conversion of GSSG to GSH by GR or in activities of phase I 
biotransformation enzymes. Significant increases in IDP activities have been reported in digestive glands of blue mussels exposed to hydrocarbons and increased NAPDH generation have been described in liver of Zebrafish exposed to brominated flame retardants (Widdows et al., 1982; Lima et al., 2007; Kling and Förlin, 2009). These results could indicate a coordinated regeneration of NADPH and GSH for ROS scavenging and xenobiotic biotransformation in native harbor mussel digestive glands. In particular, they could be involved in the increased need of GSH associated with higher GST activities described above in the same organ, which is supported by the positive covariance of GR, IDP and GST in the PCA analysis.

Biochemical changes observed in native harbor mussels (Cp) are expected to be energetically costly and lead to increased energy production (Kültz, 2005; Sokolova et al., 2012). Here, no change was observed for the glycolytic enzyme PK in digestive glands of native harbor mussels (Cp) but higher PEPCK activities suggested increased gluconeogenesis compared to non-exposed mussels (Ar). This could traduce higher energy storage (e.g. in the form of glycogen) in these mussels but could also be explained by an increased need of glucose to fulfill alternative metabolic routes such as the pentose-phospate pathway in order to increase NADPH production to combat oxidative stress as hypothesized by Lou (2003). These results, along with higher IDP activities described above in the same organ, gave further indication of increased NADPH production in native harbor mussels (Cp). Similar increases in gluconeogenesis along with higher NADPH production have been described in liver of Zebrafish exposed to brominated flame retardants (Kling and Förlin, 2009). Besides, shift from prooxidant NADH-producing to antioxidant NADPH-producing and -consuming metabolic pathways has been recently proposed as an adaptive strategy to face the threat from the increased ROS production in marine organisms exposed to environmental stress (Tomanek, 2014). Higher PEPCK activities could also traduce increased anaerobic metabolism in native harbor mussels. Increased anaerobic metabolism has been previously described in mussels caged in anthropogenically-impacted sites by Fasulo et al. (2012). However, this hypothesis is unlikely since in the PEP-branchpoint, PEP diverts into the PEPCK reaction due to PK inhibition but no changes were observed in PK activities in the present study (Greenway and Storey, 1999).

Overall, the induction of antioxidant defenses (including GST), reducing equivalents generation and gluconeogenesis suggests an increase ROS generation in digestive glands of native harbor mussels. ROS could be generated directly by contaminants but also indirectly by increased aerobic metabolism to sustain energetic costs of metabolic response to contaminants, since the electron transport chain is a major site of ROS production (Murphy, 2009; Regoli and Giulani, 2014). The existence of oxidative pressure is confirmed by multivariate analyses performed on redox-related responses that suggested a different redox status of the two native mussel groups (Ar and Cp). 
Oxidative pressure potentially leads to oxidative damage such as lipid peroxidation if antioxidant mechanisms are not sufficient to maintain a balance between the generation and neutralization of ROS. Lipid peroxidation in mussels inhabiting polluted areas has been reported by several studies (Lima et al., 2007; Vlahogianni et al., 2007). However, here, higher lipid peroxidation levels were not observed in digestive glands of native harbor mussels ( $\mathrm{Cp}$ ) compared to non-exposed mussels (Ar), suggesting activation of ROS scavenging mechanisms was able to protect macromolecules against oxidative damage.

Chronic pollution potentially leads to health alteration in exposed mussels. Pampanin et al. (2005) have previously reported decreased condition index in native mussels inhabiting polluted areas in the Venice Lagoon (Italy). Here, mussels physiological condition did not seem affected by contamination in native harbor mussels (Cp) as no significant differences were observed in condition index compared to non-exposed ones (Ar), indicating an absence of acute chemical stress or physiological impairment in native harbor mussels $(\mathrm{Cp})$. Overall, these results suggested native harbor mussels have set up a coordinated metabolic response to detoxify contaminants and face oxidative stress, which could contribute to reduce its deleterious effects on cells.

\subsection{Effects of chemical contamination on biomarker responses in caged mussels}

In caged mussels (Tr), significantly lower GR activities were measured in gills compared to non-exposed mussels (Ar) traducing disturbances of antioxidant defenses and suggesting an inhibition of antioxidant capacity. GR is considered as very sensitive to environmental pollution and similar decreases in GR activities have been observed by Bocchetti et al. (2008) in digestive glands of blue mussels caged in the harbor of Piombino (Tuscany, Italy) during dredging and disposal operations. However, in the present study, no other significant differences were observed between caged ( $\mathrm{Tr}$ ) and non-exposed mussels (Ar) at the biochemical level indicating a weak response in caged mussels after one month of transplantation in the moderately contaminated harbor of Brest. This is confirmed by multivariate analysis, which did not identify segregation in any organs between the two mussel groups. Similarly at the transcriptional level, we previously showed that only one gene involved in DNA repair (Growth arrest and DNA damage inducible gene $45 \alpha$ ) was found differentially regulated between the two mussel groups (Lacroix et al., 2014a). This relative lack of response in caged mussels ( $\mathrm{Tr}$ ) which had significantly accumulated contaminants, is rather surprising since stress responses, such as antioxidant defenses, are known to be highly inducible, especially in sessile intertidal organisms adapted to a highly stressful environment (Zhang et al., 2012). Regarding condition index, after one-month of caging, $\mathrm{Tr}$ mussels did not show significant differences compared to reference mussels (Ar). Previous studies have shown that one-month caging, though potentially too short 
to detect changes in condition index, was enough to detect changes in antioxidant markers (Regoli et al., 2004; Pampanin et al, 2005; Bocchetti et al., 2008; Giarratano et al, 2010; Cappello et al., 2013; Turja et al., 2013). Further caging experiments are needed to better understand responses observed.

\subsection{Comparison of native and caged mussels responses}

Though exposed to common environmental conditions, caged and native harbor mussels displayed distinctive biological responses, which confirms responses observed at the transcriptional level (Lacroix et al., 2014a). Several studies have previously reported differences in response between caged and native organisms exposed to environmental pollution. Observed differences were attributed to several factors: absence of cumulative long-term effects of pollutants in caged organisms (Nigro et al., 2006); or the existence of adaptive traits or compensatory mechanisms in native mussels chronically exposed to pollution, leading for example to lower bioaccumulation levels than in short-term caged organisms or to significant differences in biomarker responses (Regoli and Principato, 1995; Marigómez et al., 2013; Greenfield et al., 2014).

Here, two-fold higher PAH concentrations were measured in digestive glands of caged (Tr) compared to native harbor mussels $(\mathrm{Cp})$ traducing differences in PAH bioaccumulation levels between caged (Tr) and native harbor (Cp) mussels. Xenobiotic bioaccumulation is a balance between uptake and direct excretion or elimination via metabolization (Liu et al., 2014). Therefore, observed differences could stem from an adaptive response to pollution in native harbor mussels, resulting in either higher excretion, lower pollutants uptake and/or higher biotransformation rates (Widdows et al., 1983; Khan et al., 2011).

Significantly lower GST activities were measured in gills of caged mussels (Tr) and a similar trend was observed in digestive gland, suggesting lower biotransformation rates in caged mussels (Tr), which could contribute to the higher PAHs bioaccumulation observed compared to native harbor mussels $(\mathrm{Cp})$. Regarding antioxidant defenses, significantly higher Tot-SOD, CuZn-SOD and CAT where measured in gills and/or digestive glands of native harbor mussels (Cp), indicating a higher antioxidant capacity in native mussels for both organs. Similarly, higher IDP activities in digestive glands of native mussels (Cp) indicated higher NADPH generation compared to caged ones (Tr). Regarding energetic metabolism, significantly higher PEPCK activities indicated higher gluconeogenesis in native mussels digestive glands. This was confirmed by significantly lower PK/PEPCK ratios in the same organ, suggesting a slow down of glycolysis and an activation of gluconeogenesis in native harbor mussels $(\mathrm{Cp})$ compared to caged ones $(\mathrm{Tr})$ to potentially increase cellular energy conservation or channeled glucose into NADPH generation pathways to combat oxidative stress as described in the section 4.2. These 
results indicate higher biotransformation, antioxidant capacity, NADPH generation and gluconeogenesis in native mussels $(\mathrm{Cp})$ compared to caged ones ( $\mathrm{Tr}$ ).

Regarding lipid peroxidation, significantly higher MDA levels were observed in native mussels ( $\mathrm{Cp}$ ), traducing higher oxidative damage compared to caged ones (Tr). As both mussels groups are exposed to contaminants, we could hypothesize differences observed are caused by differences in aerobic metabolism rates. There is probably an activation of aerobic metabolism in native mussels $(\mathrm{Cp})$ digestive glands in order to fulfill the energetic demand associated with xenobiotic and ROS metabolisms activation, leading to an increase ROS generation and lipid peroxidation (Murphy, 2009; Sokolova et al., 2012).

Overall, differences observed gave further proofs of the existence of metabolic adaptive responses in native harbor mussels chronically exposed to contamination, which are not induced in caged mussels after one-month exposure.

\section{Conclusion}

In the present study, the ecotoxicological status of Brest harbor was assessed. Results indicated the existence of a moderate anthropogenic contamination compared to other large harbors and urban areas regarding PAH compounds. The existence of a chemical pressure was confirmed by modulation of biomarkers in native harbor mussel digestive glands. However, no sign of acute chemical stress were detected suggesting chronically exposed mussels were able to survive in the moderately contaminated Brest harbor. This could be explained by the set up of a coordinated response against chemically-induced cellular stress, which could contribute to, at least partially, offset the deleterious effects of contaminants. This cellular stress response consisted in activation of biotransformation, antioxidant defenses, reducing equivalents generation and gluconeogenesis in digestive glands of chronically exposed mussels.

From a methodological point of view, this study provides further evidence of the usefulness of biomarker approach in biomonitoring study. In particular, energy-related biomarkers appeared to give important information on the metabolic pattern of organisms, and allowed a better understanding of biological responses. They should be generalized in biomonitoring studies to complement more traditional biomarkers as suggested by Sokolova et al. (2012). Regarding target organs, results supported the fact that gills and digestive glands are organs of choice for pollution biomonitoring (Porte et al., 2001; Manduzio et al., 2004; Lima et al., 2007), since they both exhibited biochemical biomarker responses and site-effects as shown by multivariate analyses. However, it should be noted that for biochemical parameters taken individually, differences between non-exposed (Ar) and native harbor mussels $(\mathrm{Cp})$ were mostly detected in the digestive gland, contrasting with the results observed on the same mussels at the transcriptional level, where gills seemed to be the most responsive organ (Lacroix et al., 2014a). 
This confirmed the existence of discrepancies between the responses observed at the transcriptional- and the protein- levels (Regoli and Giuliani, 2014). Lastly, comparison of active and passive biomonitoring has highlighted different physiological responses in native and caged mussels. Overall, unlike previous observations (Regoli and Principato, 1995; Marigómez et al., 2013), this study suggested that native individuals could be better sentinels as they showed more sensitive biomarker responses. They may also be more environmentally relevant since their responses reflect the long-term effects of contamination. On the other hand, caged organisms could be more suitable as bioindicator organisms to assess contamination levels since they may not display increased pollutant elimination rates resulting from adaptation, which could lead to an underestimation of contamination levels in native mussels. This confirmed that active and passive approaches are complementary and should be used in parallel for a better assessment of contamination impacts.

\section{Authors contribution}

Designed the caging experiment: CL, DM, MA. Performed the analyses: CL, GR, CS. Analyzed the data: CL, GR, CS, JG, DM, MA. Wrote the paper: CL, DM, MA.

\section{Acknowledgements}

The authors wish to express their sincere thanks to Sébastien Artigaud, Vianney Pichereau and two anonymous reviewers for their helpful comments on the manuscript, Ewan Harney and Marie Héloury for English correction and Olivier Gauthier for assistance with statistical analyses. The authors also thank Jean-Philippe Béguel, Valérie Coquillé, Morgana Tagliarolo, Malwenn Lassudrie, Cédric Le Bris, Claire Hémon, Justine Receveur, Axel Haurie, Thierry Le Bec and Isabelle Bihannic for their help and technical assistance. This project was supported by the ANR-NSERC "IPOC" program (2013-2015; ANR-12-ISV7-0004). Camille Lacroix also received fundings from the "Région Bretagne" and from the "Université de Bretagne Occidentale". 


\section{References}

Aebi, H. (1984). Catalase in Vitro. Methods in enzymology 105, 121-126.

Andral, B., Stanisiere, J. Y., Sauzade, D., Damier, E., Thebault, H., Galgani, F., and Boissery, P. (2004). Monitoring chemical contamination levels in the Mediterranean based on the use of mussel caging. Marine Pollution Bulletin 49, 704-712.

Anestis, A., Pörtner, H. O., Karagiannis, D., Angelidis, P., Staikou, A., and Michaelidis, B. (2010). Response of Mytilus galloprovincialis (L.) to increasing seawater temperature and to marteliosis: Metabolic and physiological parameters. Comparative Biochemistry and Physiology, Part A 156, 57-66.

Besse, J.-P., Geffard, O., and Coquery, M. (2012). Relevance and applicability of active biomonitoring in continental waters under the Water Framework Directive. Trends in Analytical Chemistry 36, 113127.

Béguel, J.-P., Huvet, A., Quillien, V., Lambert, C., and Fabioux, C. (2013). Study of the antioxidant capacity in gills of the Pacific oyster Crassostrea gigas in link with its reproductive investment. Comparative Biochemistry and Physiology, Part C 157, 63-71.

Bierne, N., Borsa, P., Daguin, C., Jollivet, D., Viard, F., Bonhomme, F., et David, P. (2003). Introgression patterns in the mosaic hybrid zone between Mytilus edulis and M. galloprovincialis. Molecular Ecology $12,447-461$.

Bocchetti, R., Fattorini, D., Pisanelli, B., Macchia, S., Olivero, L., Pilato, F., Pellegrini, D., and Regoli, F. (2008). Contaminant accumulation and biomarker responses in caged mussels, Mytilus galloprovincialis, to evaluate bioavailability and toxicological effects of remobilized chemicals during dredging and disposal operations in harbour areas. Aquatic Toxicology 89, 257-266.

Cameselle, J. C., Sánchez, J. L. and Carrión (1980). The regulation of glycolysis in the hepatopancreas of the sea mussel Mytilus edulis L. Comparative Physiology and Biochemistry, Part B 65, 95-102.

Cappello, T., Maisano, M., D'Agata, A., Natalotto, A., Mauceri, A., and Fasulo, S. (2013). Effects of environmental pollution in caged mussels (Mytilus galloprovincialis). Marine Environmental Research $91,52-60$.

Cribb, A. E., Leeder, J. S., and Spielberg, S. P. (1989). Use of a Microplate Reader in an Assay of Glutathione Reductase Using 5,5'-Dithiobis(2-nitrobenzoic Acid)'. Analytical Biochemistry 183, 195-196.

Dabrowska, H., Kopko, O., Turja, R., Lehtonen, K. K., Góra, A., Polak-Juszczak, L., Warzocha, J. and Kholodkevich, S. (2013). Sediment contaminants and contaminant levels and biomarkers in caged mussels (Mytilus trossulus) in the southern Baltic Sea. Marine Environmental Research 84, 1-9.

Depledge, M. H., and Fossi, M. C. (1994). The role of biomarkers in environmental assessment (2). Invertebrates. Ecotoxicology 3, 161-172.

De Zwaan, A., Van Marrewijk, W. J. A. (1973). Intracellular localization of pyruvate carboxylase, phosphoenolpyruvate carboxykinase and "malic enzyme" and the absence of glyoxylate cycle enzymes in the sea mussel (Mytilus edulis L.). Comparative Biochemistry and Physiology, Part B 44, 1057-1066.

Donval, A., et Plana, S. (1997). Lysosomal changes in the digestive glands of bivalves in the Bay of Brest. Annales de l'Institut Océanographique 73, 69-76.

Doyen, P., Bigot, A., Vasseur, P., and Rodius, F. (2008). Molecular cloning and expression study of pi-class glutathione S-transferase (pi-GST) and selenium-dependent glutathione peroxidase (Se-GPx) transcripts in the freshwater bivalve Dreissena polymorpha. Comparative Biochemistry and Physiology Part C: Toxicology \& Pharmacology 147, 69-77.

European Commission. Directive 2008/56/EC of the European Parliament and of the Council of 17 June 2008 establishing a framework for community action in the field of marine environmental policy 
(Marine Strategy Framework Directive). Official Journal of the European Union, L 164/19.

Farrington, J. W., Goldberg, E. D., Risebrough, R. W., Martin, J. H., and Bowen, V. T. (1983). U.S. "Mussel Watch" 1976-1978: an overview of the trace-metal, DDE, PCB, hydrocarbon and artificial radionuclide data. Environmental Science and Technology 17, 490-496.

Fasulo, S., Iacono, F., Cappello, T., Corsaro, C., Maisano, M., D'Agata, A., Giannetto, A., De Domenico, E., Parrino, V., Paro, Lo, G., et al. (2012). Metabolomic investigation of Mytilus galloprovincialis (Lamarck 1819) caged in aquatic environments. Ecotoxicology and Environmental Safety 84, 139-146.

Giarratano, E., Duarte, C. A., and Amin, O. A. (2010). Biomarkers and heavy metal bioaccumulation in mussels transplanted to coastal waters of the Beagle Channel. Ecotoxicology and Environmental Safety 73, 270-279.

Glémarec, M. (1997). The Bay of Brest: Environmental disturbance and its impact on the biota. Annales de l'Institut Océanographique 71, 113-122.

Gorbi, S., Virno Lamberti, C., Notti, A., Benedetti, M., Fattorini, D., Moltedo, G., and Regoli, F. (2008). An ecotoxicological protocol with caged mussels, Mytilus galloprovincialis, for monitoring the impact of an offshore platform in the Adriatic sea. Marine Environmental Research 65, 34-49.

Gowland, B. T. G., McIntosh, A. D., Davies, I. M., Moffat, C. F., and Webster, L. (2002). Implications from a field study regarding the relationship between polycyclic aromatic hydrocarbons and glutathione Stransferase activity in mussels. Marine Environmental Research 54, 231-235.

Greenfield, R., Brink, K., Degger, N., and Wepener, V. (2014). The usefulness of transplantation studies in monitoring of metals in the marine environment: South African experience. Marine Pollution Bulletin $85,566-573$.

Greenway, S. C., and Storey, K. B. (1999). The effect of prolonged anoxia on enzyme activities in oysters (Crassostrea virginica) at different seasons. Journal of Experimental Marine Biology and Ecology 242, 259-272.

Guermeur, E., Guillou, D., Miry, C., Almanza, A. and Treguer-Herrou, V. (2005). Les organo-étains dans la Rade de Brest, Évolution dans l'eau et les sediments (Année 2005). p44.

Guévélou, E., Huvet, A., Sussarellu, R., Milan, M., Guo, X., Li, L., Zhang, G., Quillien, V., Daniel, J.-Y., Quéré, C., et al. (2013). Regulation of a truncated isoform of AMP-activated protein kinase $\alpha$ (AMPK $\alpha$ ) in response to hypoxia in the muscle of Pacific oyster Crassostrea gigas. Journal of Comparative Physiology B 183, 597-611.

Huet, M., Paulet, Y. M., and Glémarec, M. (1996). Tributyltin (TBT) Pollution in the Coastal Waters of West Brittany as Indicated by Imposex in Nucella lapillus. Marine Environmental Research 41, 157-167.

Ifremer (2006). Résultats de la Surveillance de la Qualité du Milieu Marin Littoral Département : Finistère. Edition 2006. p91.

Inoue, K., Waite, J. H., Matsuoka, M., Odo, S., and Harayama, S. (1995). Interspecific variations in adhesive protein sequences of Mytilus edulis, M. galloprovincialis, and M. trossulus. Biological Bulletin 189, 370375.

Khan, F. R., Irving, J. R., Bury, N. R., and Hogstrand, C. (2011). Differential tolerance of two Gammarus pulex populations transplanted from different metallogenic regions to a polymetal gradient. Aquatic Toxicology 102, 95-103.

Kijewski, T., Śmietanka, B., Zbawicka, M., Gosling, E., Hummel, H., et Wenne, R. (2011). Distribution of Mytilus taxa in European coastal areas as inferred from molecular markers. Journal of Sea Research 65, 224-234.

Kling, P. and Förlin, L. (2009). Proteomic studies in zebrafish liver cells exposed to the brominated flame retardants HBCD and TBBPA. Ecotoxicology and Environmental Safety 72, 1985-1993. 
Kültz, D. (2005). Molecular and evolutionary basis of the cellular stress response. Annual Review of Physiology 67, 225-257.

Lacroix, C., Coquillé, V., Guyomarch, J., Auffret, M., and Moraga, D. (2014a). A selection of reference genes and early-warning mRNA biomarkers for environmental monitoring using Mytilus spp. as sentinel species. Marine Pollution Bulletin 86, 304-313.

Lacroix, C., Le Cuff, N., Receveur, J., Moraga, D., Auffret, M., and Guyomarch, J. (2014b). Development of an innovative and "green" stir bar sorptive extraction-thermal desorption-gas chromatography-tandem mass spectrometry method for quantification of polycyclic aromatic hydrocarbons in marine biota. Journal of Chromatography A 1349, 1-10.

Lawrence, R. A., and Burk, R. F. (1976). Glutathione Peroxidase Activity in Selenium-Deficient Rat Liver. Biochemical and Biophysical Research Communications 71, 952-958.

Lima, I., Moreira, S. M., Osten, J. R., Soares, A. M. V. M., and Guilhermino, L. (2007). Biochemical responses of the marine mussel Mytilus galloprovincialis to petrochemical environmental contamination along the North-western coast of Portugal. Chemosphere 66, 1230-1242.

Liu, D., Pan, L., Li, Z., Cai, Y., and Miao, J. (2014). Metabolites analysis, metabolic enzyme activities and bioaccumulation in the clam Ruditapes philippinarum exposed to benzo[a]pyrene. Ecotoxicology and Environmental Safety 107, 251-259.

Lockwood, B. L., and Somero, G. N. (2012). Functional Determinants of Temperature Adaptation in Enzymes of Cold- versus Warm-Adapted Mussels (Genus Mytilus). Molecular Biology and Evolution $29,3061-3070$.

Lou, M. F. (2003). Redox regulation in the lens. Progress in Retinal and Eye Research 22, 657-682

Manduzio, H., Monsinjon, T., Galap, C., Leboulenger, F., and Rocher, B. (2004). Seasonal variations in antioxidant defences in blue mussels Mytilus edulis collected from a polluted area: major contributions in gills of an inducible isoform of $\mathrm{Cu} / \mathrm{Zn}$-superoxide dismutase and of glutathione $\mathrm{S}$ transferase. Aquatic Toxicology 70, 83-93.

Manduzio, H., Monsinjon, T., Rocher, B., Leboulenger, F., and Galap, C. (2003). Characterization of an inducible isoform of the $\mathrm{Cu} / \mathrm{Zn}$ superoxide dismutase in the blue mussel Mytilus edulis. Aquatic Toxicology 64, 73-83.

Manoli, E., and Samara, C. (1999). Polycyclic aromatic hydrocarbons in natural waters- sources, occurrence and analysis. Trends in Analytical Chemistry 18, 1-12.

Marigómez, I., Zorita, I., Izagirre, U., Ortiz-Zarragoitia, M., Navarro, P., Etxebarria, N., Orbea, A., Soto, M., and Cajaraville, M. P. (2013). Combined use of native and caged mussels to assess biological effects of pollution through the integrative biomarker approach. Aquatic Toxicology 136-137, 32-48.

McFarland, V. M., Inouye, L. S., Lutz, C. H., Jarvis, A. S., Clarke, J. U., and McCant, D. D. (1999). Biomarkers of Oxidative Stress and Genotoxicity in Livers of Field-Collected Brown Bullhead, Ameiurus nebulosus. Archives of Environmental Contamination and Toxicology 37, 236-241.

Melwani, A. R., Gregorio, D., Jin, Y., Stephenson, M., Ichikawa, G., Siegel, E., Crane, D., Lauenstein, G., and Davis, J. A. (2014). Mussel watch update: Long-term trends in selected contaminants from coastal California, 1977-2010. Marine Pollution Bulletin 81, 292-302.

Michel, P. and Averty, B. (1997). Tributyltin contamination in the Bay of Brest. Annales de l'Institut Océanographique 73, 25-34.

Monserrat, J. M., Martínez, P. E., Geracitano, L. A., Lund Amado, L., Martinez Gaspar Martins, C., Lopes Leães Pinho, G., Soares Chaves, I., Ferreira-Cravo, M., Ventura-Lima, J., and Bianchini, A. (2007). Pollution biomarkers in estuarine animals: Critical review and new perspectives. Comparative Biochemistry and Physiology Part C: Toxicology \& Pharmacology 146, 221-234. 
Moore, M. N., Livingstone, D. R., Donkin, P., Bayne, B. L., Widdows, J., and Lowe, D. M. (1980). Mixed function oxygenases and xenobiotic detoxication:toxication systems in bivalve molluscs. Helgoländer Meeresunters 33, 278-291.

Murphy, M. P. (2009) How mitochondria produce reactive oxygen species. Biochemical Journal 417, 1-13.

Nigro, M., Falleni, A., Barga, I. D., Scarcelli, V., Lucchesi, P., Regoli, F., and Frenzilli, G. (2006). Cellular biomarkers for monitoring estuarine environments: Transplanted versus native mussels. Aquatic Toxicology 77, 339-347.

Okumuş, I., and Stirling, H. P. (1998). Seasonal variations in the meat weight, condition index and biochemical composition of mussels (Mytilus edulis L.) in suspended culture in two Scottish sea lochs. Aquaculture 159, 249-261.

OSPAR Commission. (2009). Status and trend of marine chemical pollution, Hazardous substances series.

Oubella, R. (1997). Immunomodulation in populations of bivalve molluscs from the Bay of Brest. Annales de l'Institut Océanographique 73, 77-87.

Pampanin, D. M., Volpato, E., Marangon, I., and Nasci, C. (2005). Physiological measurements from native and transplanted mussel (Mytilus galloprovincialis) in the canals of Venice. Survival in air and condition index. Comparative Biochemistry and Physiology Part A: Molecular \& Integrative Physiology 140, 41-52.

Pamplona, R., and Costantini, D. (2011). Molecular and structural antioxidant defenses against oxidative stress in animals. AJP: Regulatory, Integrative and Comparative Physiology 301, R843-R863.

Porte, C., Solé, P., Borghi, V., Martinez, M., Chamorro, J., Torreblanca, A., Ortiz, M., Orbea, A., Soto, M., and Cajarville, M. P. (2001). Chemical, biochemical and cellular responses in the digestive gland of the mussel Mytilus galloprovincialis from the Spanish Mediterranean coast. Biomarkers 6, 335-350.

Quiniou, F., Judas, A. and Le Squer-Andre, E. (1997). Assessment of potential toxicity in estuary water and sediments in the Bay of Brest using two types of bioassay. Annales de l'Institut Océanographique 73, $35-48$.

Regoli, F., and Giuliani, M. E. (2014). Oxidative pathways of chemical toxicity and oxidative stress biomarkers in marine organisms. Marine Environmental Research 93, 106-117.

Regoli, F., and Principato, G. (1995). Glutathione, glutathione-dependent and antioxidant enzymes in mussel, Mytilus galloprovincialis, exposed to metals under field and laboratory conditionsimplications for the use of biochemical biomarkers. Aquatic Toxicology 31, 143-164.

Regoli, F., Frenzilli, G., Bocchetti, R., Annarumma, F., Scarcelli, V., Fattorini, D., and Nigro, M. (2004). Timecourse variations of oxyradical metabolism, DNA integrity and lysosomal stability in mussels, Mytilus galloprovincialis, during a field translocation experiment. Aquatic Toxicology 68, 167-178.

Regoli, F., Pellegrini, D., Cicero, A. M., Nigro, M., Benedetti, M., Gorbi, S., Fattorini, D., D’Errico, G., Di Carlo, M., Nardi, A., et al. (2014). A multidisciplinary weight of evidence approach for environmental risk assessment at the Costa Concordia wreck: Integrative indices from Mussel Watch. Marine Environmental Research 96, 92-104.

Rocher, B., Le Goff, J., Peluhet, L., Briand, M., Manduzio, H., Gallois, J., Devier, M. H., Geffard, O., Gricourt, L., Augagneur, S., et al. (2006). Genotoxicant accumulation and cellular defence activation in bivalves chronically exposed to waterborne contaminants from the Seine River. Aquatic Toxicology 79, 65-77.

Ruiz, Y., Suarez, P., Alonso, A., Longo, E., Villaverde, A., and Juan, F. S. (2011). Environmental quality of mussel farms in the Vigo estuary: Pollution by PAHs, origin and effects on reproduction. Environmental Pollution 159, 250-265.

Serafim, A., Lopes, B., Company, R., Cravo, A., Gomes, T., Sousa, V., and Bebianno, M. J. (2011). A multibiomarker approach in cross-transplanted mussels Mytilus galloprovincialis. Ecotoxicology 20, 1959- 
1974.

Sericano, J. L., Wade, T. L., Jackson, T. J., Brooks, J. M., Tripp, B. W., Farrington, J. W., Mee, L. D., Readmann, J. W., Villeneuve, J.-P., and Goldberg, E. D. (1995). Trace Organic Contamination in the Americas- An Overview of the US National Status \& Trends and the International "Mussel Watch" Programmes. Marine Pollution Bulletin 31, 214-225.

Sokolova, I. M., Frederich, M., Bagwe, R., Lannig, G., and Sukhotin, A. A. (2012). Energy homeostasis as an integrative tool for assessing limits of environmental stress tolerance in aquatic invertebrates. Marine Environmental Research 79, 1-15.

Sussarellu, R., Fabioux, C., Sanchez, M. C., Le Goïc, N., Lambert, C., Soudant, P., and Moraga, D. (2012). Molecular and cellular response to short-term oxygen variations in the Pacific oyster Crassostrea gigas. Journal of Experimental Marine Biology and Ecology 412, 87-95.

R Core Team (2013). R: A language and environment for statistical computing. (Vienna, Austria: R Foundation for Statistical Computing). Available at: http://www.R-project.org/.

Tomanek, L. (2014). Proteomics to study adaptations in marine organisms to environmental stress. Journal of Proteomics 105, 92-106

Turja, R., Soirinsuo, A., Budzinski, H., Devier, M.-H. and Lethonen, K. K. (2013). Biomarker responses and accumulation of hazardous substances in mussels (Mytilus trossulus) transplanted along a pollution gradient close to an oil terminal in the Gulf of Finland (Baltic Sea). Comparative Biochemistry and Physiology, Part C 157, 80-92.

Turja, R., Höher, N., Snoeijs, P., Baršienė, J., Butrimavičienė, L., Kuznetsova, T., Kholodkevich, S. V., Devier, M.-H., Budzinski, H. and Lethonen, K. K. (2014). A multibiomarker approach to the assessment of pollution impacts in two Baltic Sea coastal areas in Sweden using caged mussels (Mytilus trossulus). Science of the Total Environment 473-474, 398-409.

Valavanidis, A., Vlahogianni, T., Dassenakis, M., and Scoullos, M. (2006). Molecular biomarkers of oxidative stress in aquatic organisms in relation to toxic environmental pollutants. Ecotoxicology and Environmental Safety 64, 178-189.

Vidal-Liñán, L., Bellas, J., Campillo, J. A., and Beiras, R. (2010). Integrated use of antioxidant enzymes in mussels, Mytilus galloprovincialis, for monitoring pollution in highly productive coastal areas of Galicia (NW Spain). Chemosphere 78, 265-272.

Wenzl, T., Simon, R., Anklam, E., and Kleiner, J. (2006). Analytical methods for polycyclic aromatic hydrocarbons (PAHs) in food and the environment needed for new food legislation in the European Union. Trends in Analytical Chemistry 25, 716-725.

Widdows, J., Bakke, T., Bayne, B. L., Donkin, P., Livingstone, D. R., Lowe, D. M., Moore, M. N., Evans, S. V., and Moore, S. L. (1982). Responses of Mytilus edulis on Exposure to the Water-Accommodated Fraction of North Sea Oil. Marine Biology 67, 15-31.

Widdows, J., Moore, S. L., Clarke, K. R., and Donkin, P. (1983). Uptake, tissue distribution and elimination of [1-14C] naphthalene in the mussel Mytilus edulis. Marine Biology 76, 109-114.

Yan, J., Wang, L., Fu, P. P., and Yu, H. (2004). Photomutagenicity of 16 polycyclic aromatic hydrocarbons from the US EPA priority pollutant list. Mutation Research/Genetic Toxicology and Environmental Mutagenesis 557, 99-108.

Zhang, G., Fang, X., Guo, X., Li, L., Luo, R., Xu, F., Yang, P., Zhang, L., Wang, X., Qi, H., et al. (2012). The oyster genome reveals stress adaptation and complexity of shell formation. Nature 490, 49-54.

Zhang, H., Pan, L., and Tao, Y. (2014). Toxicity assessment of environmental pollutant phenanthrene in clam Venerupis philippinarum using oxidative stress biomarkers. Environmental Toxicology and Pharmacology 37, 697-704. 


\section{Figures captions:}

Figure 1: Sampling and caging (italic) locations in the Bay of Brest. Ar: Armorique (reference), Cp: Commercial Port and Tr: transplant.

Figure 2: Biotransformation biomarker: mean glutathione-S-transferase activities (GST, $\mathrm{mU} / \mathrm{mg}$ proteins) in gills and digestive glands of native and caged mussels (Ar, $\mathrm{Cp}$ and $\mathrm{Tr}$ ). Asterisks indicate significant differences (Kruskal Wallis Test). Levels of significance: $p<0.1=$ ".", $p<0.05=$ “*”, $\mathrm{p}<0.01=$ " $* * ”, \mathrm{p}<0.001=$ "***”. $(\mathrm{n}=5$, bars $=$ S.E.M. $)$.

Figure 3: Antioxidant defenses: mean total-superoxide dismutase (Tot-SOD, U/mg proteins), $\mathrm{Cu} / \mathrm{Zn}$-superoxide dismutase (CuZn-SOD, U/mg proteins), catalase (CAT, U/mg proteins) and glutathione peroxidase (GPx, $\mathrm{mU} / \mathrm{mg}$ proteins) activities in gills and digestive glands of native and caged mussels (Ar, $\mathrm{Cp}$ and $\mathrm{Tr}$ ). Asterisks indicate significant differences (Kruskal Wallis Test). Levels of significance: $\mathrm{p}<0.1=$ ".”, $\mathrm{p}<0.05={ }^{\prime *} *, \mathrm{p}<0.01={ }^{\prime * * ”} .(\mathrm{n}=5$, bars $=$ S.E.M. $)$.

Figure 4: Biomarkers involved in reducing equivalents generation: mean glutathione reductase (GR, $\mathrm{mU} / \mathrm{mg}$ proteins) and NADP-isocitrate dehydrogenase (IDP, $\mathrm{mU} / \mathrm{mg}$ proteins) activities in gills and digestive glands of native and caged mussels ( $\mathrm{Ar}, \mathrm{Cp}$ and $\mathrm{Tr}$ ). Asterisks indicate significant differences (Kruskal Wallis Test). Levels of significance: $p<0.1=$ “., $p<0.05=$ “*”, $\mathrm{p}<0.01=“ * * ” .(\mathrm{n}=5$, bars $=$ S.E.M. $)$.

Figure 5: Energetic metabolism biomarkers: mean pyruvate kinase (PK) and phosphoenolpyruvate carboxykinase (PEPCK) activities (mU/mg proteins) in gills and digestive glands of native and caged mussels ( $\mathrm{Ar}, \mathrm{Cp}$ and $\mathrm{Tr}$ ). Asterisks indicate significant differences (Kruskal Wallis Test). Levels of significance: $p<0.05=$ “*”, $p<0.01=$ “**”. $(n=5$, bars $=$ S.E.M.).

Figure 6: Mean pyruvate kinase/phosphoenolpyruvate carboxykinase activity ratios (PK/PEPCK) in digestive glands of native and caged mussels ( $\mathrm{Ar}, \mathrm{Cp}$ and $\mathrm{Tr}$ ). Asterisks indicate significant differences (Kruskal Wallis Test, $p<0.05)$. $(n=5$, bars $=$ S.E.M.).

Figure 7: Lipid peroxidation biomarker: mean malondialdehyde concentrations (MDA, nmol/g $\mathrm{WW}$ ) in gills and digestive glands of native and caged mussels ( $\mathrm{Ar}, \mathrm{Cp}$ and $\mathrm{Tr}$ ). Asterisks indicate significant differences (Kruskal Wallis Test, $\mathrm{p}<0.05$ ). Levels of significance: $\mathrm{p}<0.05={ }^{* * ”}, \mathrm{p}<0.01$ $=$ “**”. $(\mathrm{n}=5$, bars $=$ S.E.M. $)$.

Figure 8: Principal Component Analyses of antioxidant-related responses in gills and digestive glands of native and caged mussels ( $\mathrm{Ar}, \mathrm{Cp}$ and $\mathrm{Tr}$ ). Left: Factor contribution to the axes. Right: Discriminant analysis.

Figure 9: Mean condition index (CI, \%o) of native and caged mussels (Ar, $\mathrm{Cp}$ and $\mathrm{Tr}$ ) prior to and/or post caging $(n>12$, bars $=$ S.D. $)$. 


\section{Tables captions:}

Table 1: Individual PAH concentrations ( $\mu \mathrm{g} / \mathrm{kg}$ DW), sum of the 16 US EPA PAHs ( $\Sigma 16$ PAHs US $\mathrm{EPA}, \mu \mathrm{g} / \mathrm{kg} \mathrm{DW})$ in digestive glands of native and caged mussels (Ar, $\mathrm{Cp}$ and $\mathrm{Tr})(\mathrm{n}=3$, mean \pm S.D.).

Table 2: Fluoranthene (FL) and pyrene (PY) ratios in digestive glands of native and caged mussels (Ar, $\mathrm{Cp}$ and $\mathrm{Tr}$ ). 


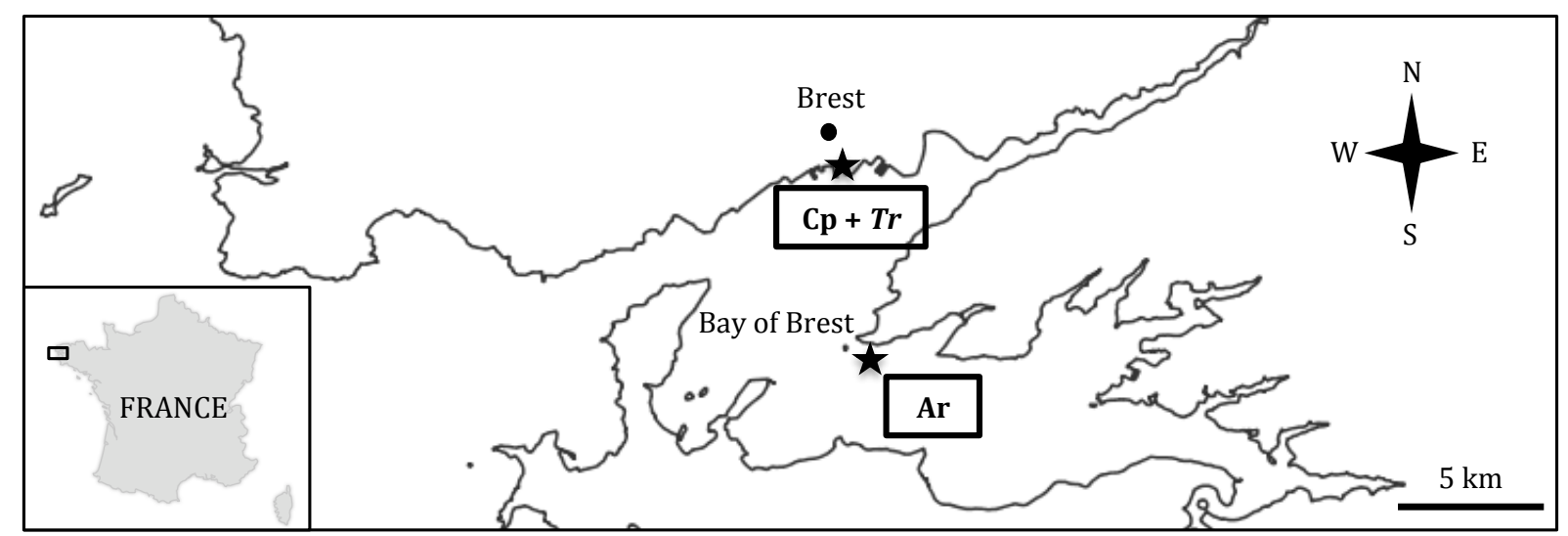




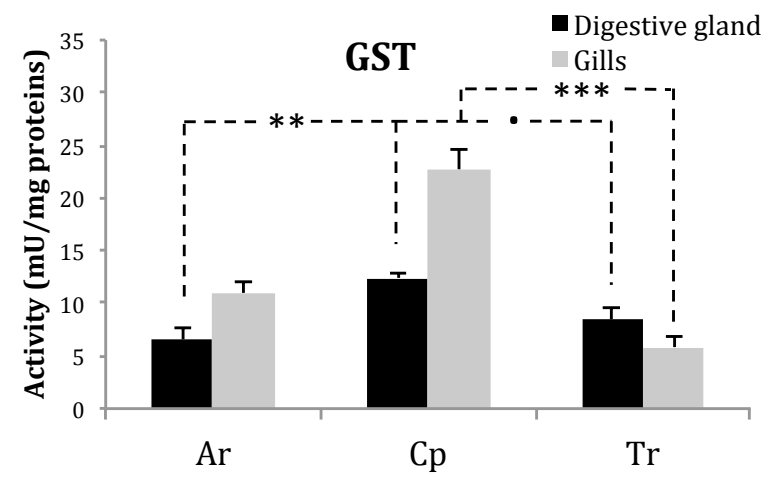



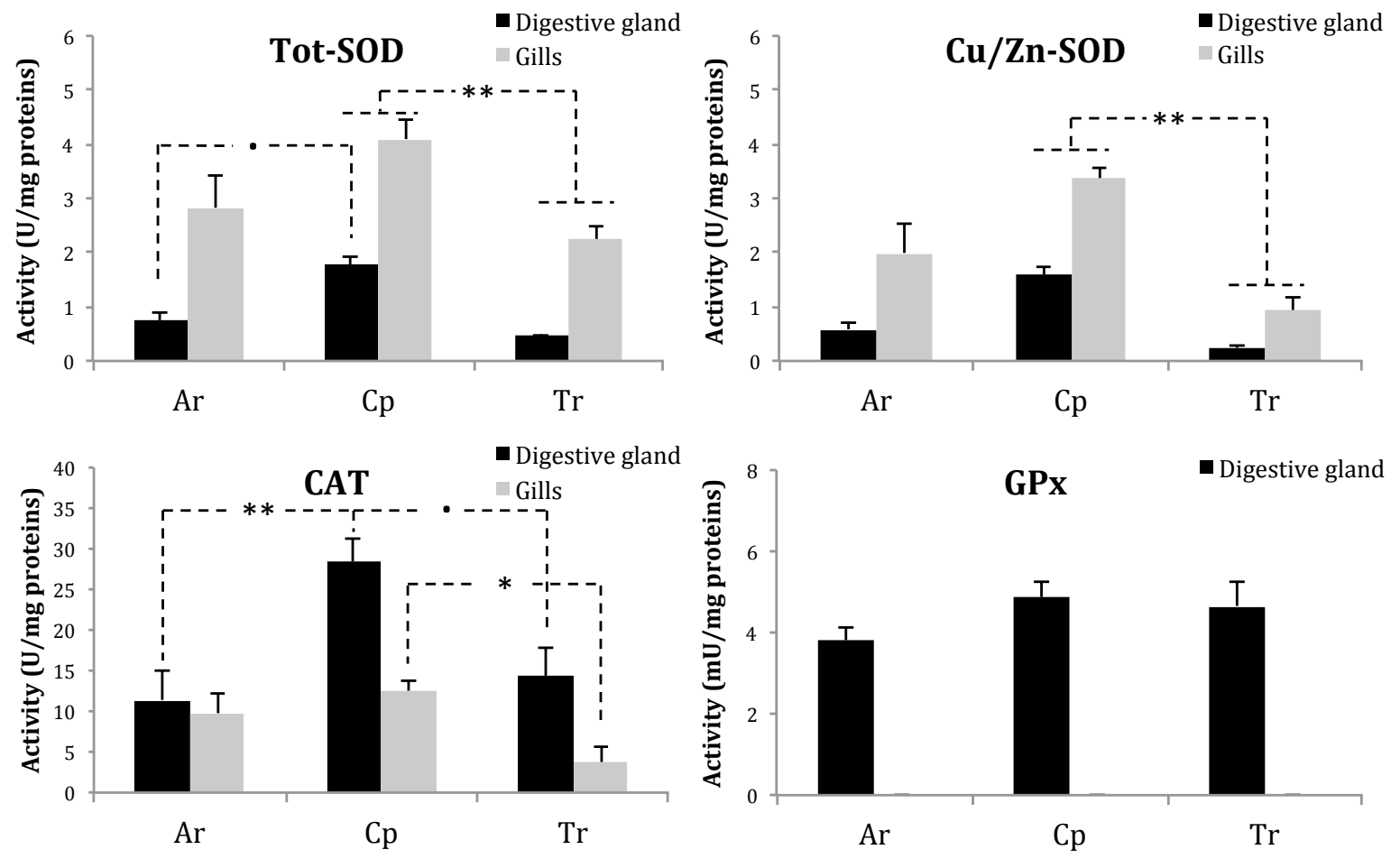

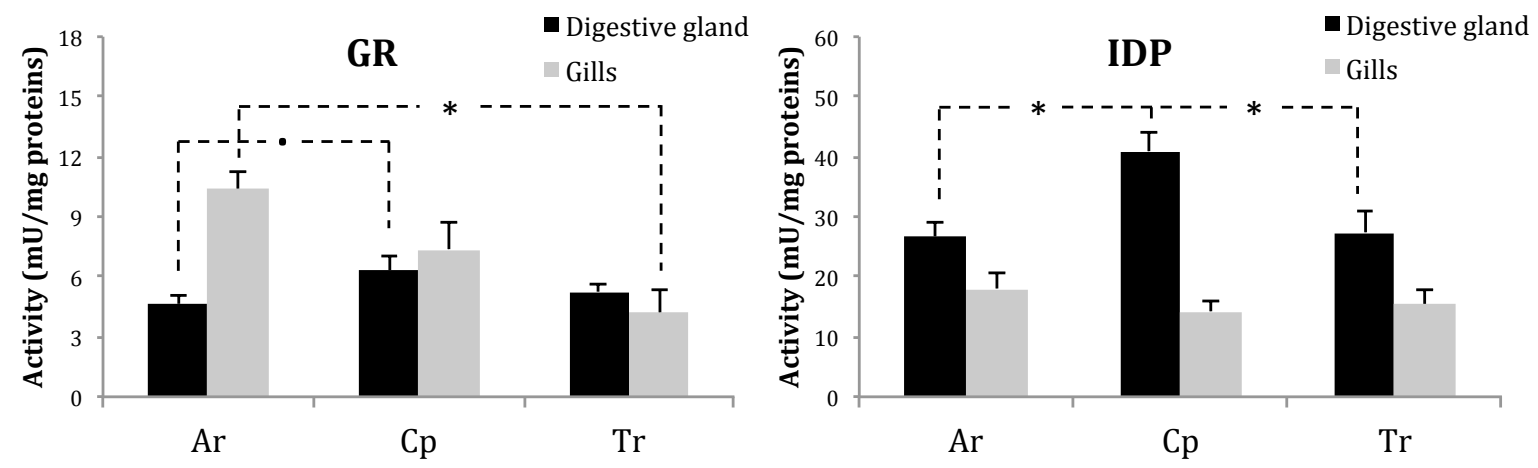


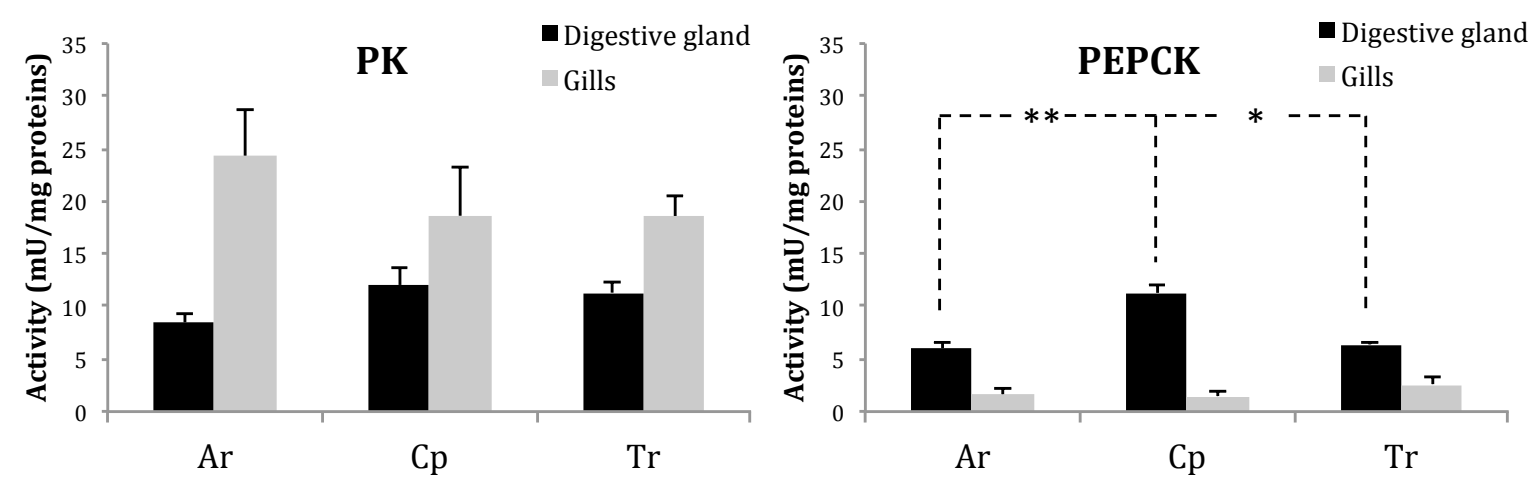




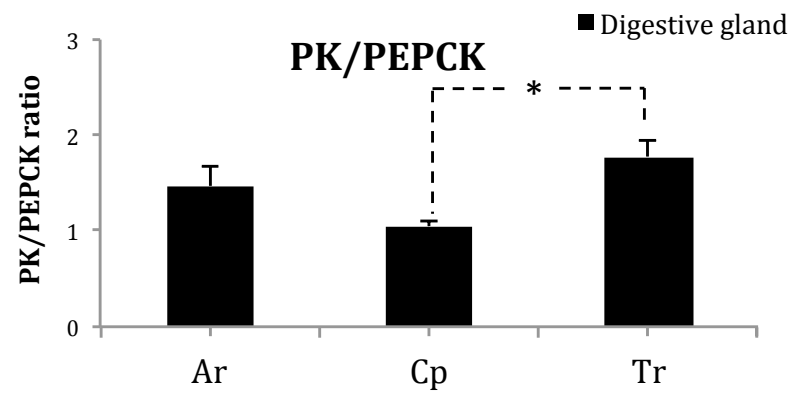




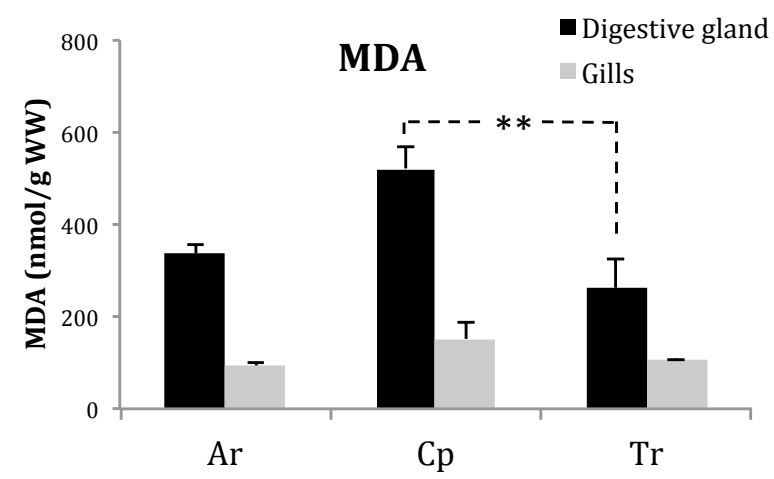




\section{Digestive gland}

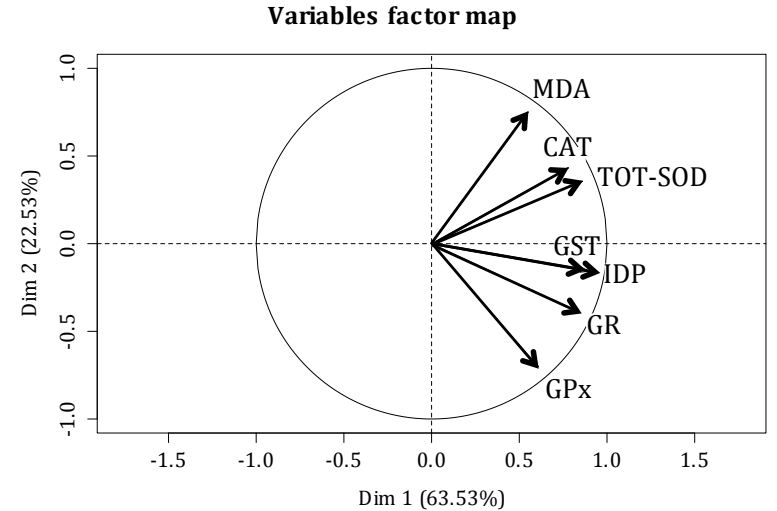

Gills

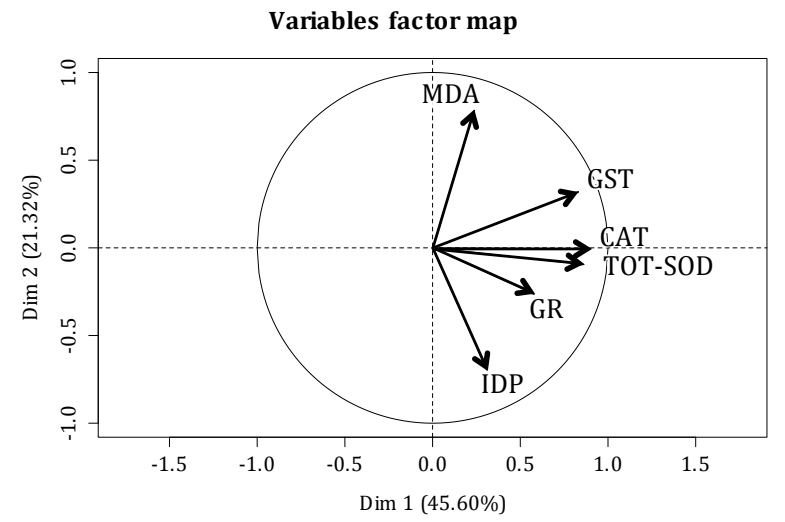

Individuals factor map

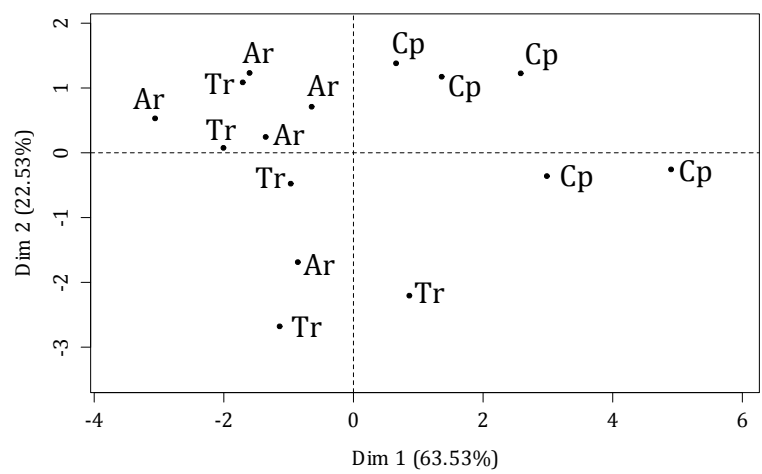

Individuals factor map

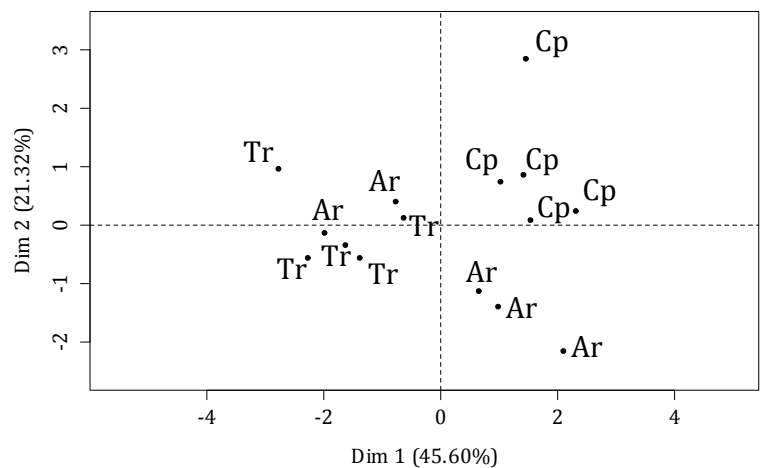




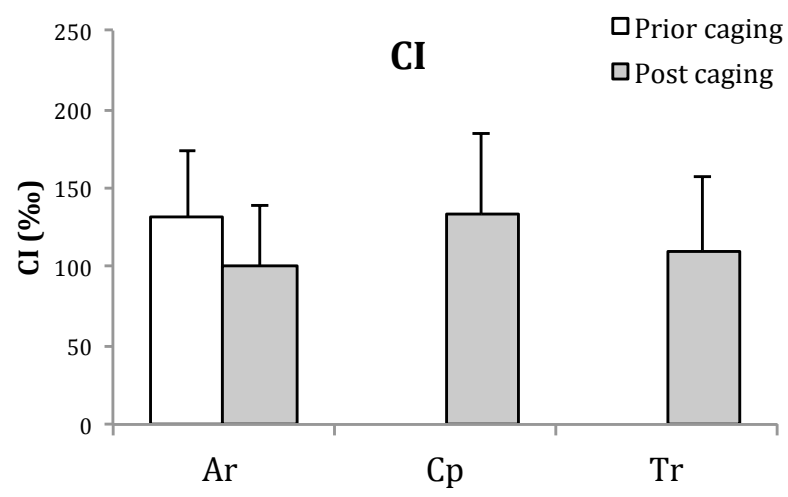




\begin{tabular}{|c|c|c|c|}
\hline \multirow{2}{*}{$\begin{array}{c}\text { PAHs } \\
(\mu \mathrm{g} / \mathrm{kg} \mathrm{DW})\end{array}$} & \multicolumn{3}{|c|}{ Sampling sites } \\
\hline & $\mathrm{Ar}$ & $\mathrm{Cp}$ & $\operatorname{Tr}$ \\
\hline $\mathrm{N}(*)$ & $4.1 \pm 0.4$ & $2.2 \pm 0.3$ & $3.9 \pm 1.0$ \\
\hline $\mathrm{BT}$ & $<$ LOQ & $<\mathrm{LOQ}$ & $<\mathrm{LOQ}$ \\
\hline $\operatorname{ANY}(*)$ & $<\mathrm{LOQ}$ & $2.0 \pm 0.5$ & $3.4 \pm 0.8$ \\
\hline ANA $(*)$ & $<\mathrm{LOQ}$ & $<$ LOQ & $<$ LOQ \\
\hline $\mathrm{F}(*)$ & $<\mathrm{LOQ}$ & $<\mathrm{LOQ}$ & $5.5 \pm 0.9$ \\
\hline DBT & $<\mathrm{LOQ}$ & $<\mathrm{LOQ}$ & $4.4 \pm 0.7$ \\
\hline $\mathrm{P}(*)$ & $<$ LOQ & $7.9 \pm 1.4$ & $21 \pm 4$ \\
\hline$A(*)$ & $<\mathrm{LOQ}$ & $3.3 \pm 0.4$ & $7.1 \pm 1.0$ \\
\hline $\mathrm{FL}\left({ }^{*}\right)$ & $<\mathrm{LOQ}$ & $14 \pm 2$ & $60 \pm 8$ \\
\hline PY $\left(^{*}\right)$ & $<\mathrm{LOQ}$ & $23 \pm 2$ & $74 \pm 10$ \\
\hline $\mathrm{BaA}\left({ }^{*}\right)$ & $<\mathrm{LOQ}$ & $16 \pm 3$ & $24 \pm 3$ \\
\hline$C(*)+\mathrm{T}$ & $<\mathrm{LOQ}$ & $28 \pm 9$ & $55 \pm 5$ \\
\hline $\mathrm{B}(\mathrm{b}+\mathrm{k}) \mathrm{F}\left({ }^{*}\right)+\mathrm{BjF}$ & $<$ LOQ & $86 \pm 26$ & $156 \pm 14$ \\
\hline $\mathrm{BeP}$ & $<\mathrm{LOQ}$ & $44 \pm 12$ & $73 \pm 9$ \\
\hline $\mathrm{BaP}\left({ }^{*}\right)$ & $<$ LOQ & $15 \pm 5$ & $25 \pm 3$ \\
\hline $\mathrm{PE}$ & $<\mathrm{LOQ}$ & $<\mathrm{LOQ}$ & $<\mathrm{LOQ}$ \\
\hline $\mathrm{IN}\left({ }^{*}\right)$ & $<\mathrm{LOQ}$ & $23 \pm 8$ & $54 \pm 6$ \\
\hline DBA $\left(^{*}\right)$ & $<\mathrm{LOQ}$ & $<\mathrm{LOQ}$ & $<\mathrm{LOQ}$ \\
\hline $\operatorname{BPE}\left(^{*}\right)$ & $<$ LOQ & $34 \pm 8$ & $38 \pm 5$ \\
\hline$\Sigma 16$ PAHs US EPA & $4.1 \pm 0.4$ & $256 \pm 36$ & $507 \pm 32$ \\
\hline
\end{tabular}

$\left(^{*}\right)$ Compounds listed as priority pollutants by US EPA

<LOQ: below the limit of quantification (Lacroix et al., 2014b) 


\begin{tabular}{ccc}
\cline { 2 - 3 } & FL/PY & FL/(FL+PY) \\
\hline $\mathrm{Ar}$ & $<\mathrm{LOQ}$ & $<\mathrm{LOQ}$ \\
$\mathrm{Cp}$ & $0.60 \pm 0.02$ & $0.37 \pm 0.01$ \\
$\mathrm{Tr}$ & $0.82 \pm 0.02$ & $0.45 \pm 0.00$ \\
\hline
\end{tabular}

<LOQ: below the limit of quantification 